\title{
How did the AD 1755 tsunami impact on sand barriers across the southern coast of Portugal?
}

\author{
Pedro J.M. Costa ${ }^{\mathrm{a}, *}$, Susana Costas ${ }^{\mathrm{b}}$, R. González-Villanueva a,c ${ }^{\mathrm{a}}$, M.A. Oliveira a , D. Roelvink ${ }^{\mathrm{d}}$, C. Andrade $^{\mathrm{a}}$, \\ M.C. Freitas ${ }^{\text {a }}$, P.P. Cunha ${ }^{\text {e }}$, A. Martins ${ }^{\text {f }}$, J.-P. Buylaert ${ }^{\text {g,h }}{ }^{\text {, A. Murray }}{ }^{\text {g }}$ \\ a Instituto Dom Luiz (IDL) and Departamento de Geologia, Faculdade de Ciências da Universidade de Lisboa, Edificio C6, Campo Grande, 1749-016 Lisboa, Portugal \\ b CIMA, Universidade do Algarve, Portugal Campus de Gambelas, Edificio 7, 8005-139 Faro, Portugal \\ c Departamento de Xeociencias Mariñas e O.T. (XM1), Universidade de Vigo, 36310 Vigo, Spain \\ d UNESCO-IHE, Delft, The Netherlands \\ e MARE - Marine and Environmental Sciences Centre and Department of Earth Sciences, Universidade de Coimbra, Rua Sílvio Lima; Univ. Coimbra - Pólo II, 3030-790 Coimbra, Portugal \\ ${ }^{\mathrm{f}}$ Centro de Geofisica, Dep. Geociências, Univ. Évora, Portugal \\ ${ }^{g}$ Nordic Laboratory for Luminescence Dating, Aarhus University, Risø DTU, Denmark \\ h Centre for Nuclear Technologies, Technical University of Denmark, Risø Campus, Denmark
}

\section{A R T I C L E I N F O}

\section{Article history:}

Received 16 October 2015

Received in revised form 6 June 2016

Accepted 14 June 2016

Available online 16 June 2016

\section{Keywords:}

Coastal dunes

Tsunami run-up

Ground penetrating radar

Tsunami inundation simulations

\begin{abstract}
A B S T R A C T
Tsunamis are highly energetic events that may destructively impact the coast. Resolving the degree of coastal resilience to tsunamis is extremely difficult and sometimes impossible. In part, our understanding is constrained by the limited number of contemporaneous examples and by the high dynamism of coastal systems. In fact, longterm changes of coastal systems can mask the evidence of past tsunamis, leaving us a short or incomplete sedimentary archive. Here, we present a multidisciplinary approach involving sedimentological, geomorphological and geophysical analyses and numerical modelling of the AD 1755 tsunami flood on a coastal segment located within the southern coast of Portugal. In particular, the work focuses on deciphering the impact of the tsunami waves over a coastal sand barrier enclosing two lowlands largely inundated by the tsunami flood. Erosional features documented by geophysical data were assigned to the AD 1755 event with support of sedimentological and age estimation results. Furthermore, these features allowed the calibration of the simulation settings to reconstruct the local conditions and establish the run-up range of the AD 1755 tsunami when it hit this coast (6$8 \mathrm{~m}$ above mean sea level). Our work highlights the usefulness of erosional imprints preserved in the sediment record to interpret the impact of the extreme events on sand barriers.
\end{abstract}

() 2016 Elsevier B.V. All rights reserved

\section{Introduction}

Geomorphological data can provide information on tsunami impacts and characteristics (e.g. inundation extent or run-up at the coast). This information is of crucial importance for coastal communities and civil authorities owing to elaborate risk reduction strategies. However, the geomorphological evidence of such impacts has been somewhat neglected, especially when compared with the study of the depositional imprints of tsunamis in coastal lowlands. The geomorphological impacts of both present-day tsunamis and palaeotsunamis have been studied over recent years (Andrade, 1992; Dawson, 1994; Goff et al., 2008, 2009; Gusman et al., 2012; Li et al., 2012; Atwater et al., 2013; Catalán et al., 2014; Kain et al., 2014; Hayakawa et al., 2015). In a seminal review focusing on the geomorphological impacts of tsunamis, Dawson (1994) discussed the relevance of coastal changes caused by

\footnotetext{
* Corresponding author.

E-mail address: ppcosta@ciencias.ulisboa.pt (P.J.M. Costa).
}

tsunami waves, not only during the inrush of the inundation but also during the backwash. He suggested that the combined effect of these processes could produce coastal landforms dominated by the effects of high-magnitude erosion and deposition. Andrade $(1990,1992)$ studied the morphological impacts caused by the AD 1755 tsunami inundation and backwash in the sandy barrier-islands of Ria Formosa (eastern Algarve, Portugal). This event caused localized drowning or truncation of foredunes and formation of extensive washovers by the incoming tsunami waves, whereas the backwash promoted the opening of short-lived inlets. Goff et al. (2009) summarized the geomorphological evidence of tsunami impacts in several sites along the New Zealand coast, including washovers, scours, hummocky topography, seaward or landward barrier scarps, remnant dune ridges and pedestals. Overwash fans could form sand sheets landward and they can later form a low-lying surface showing hummocky topography. If overwash fans remain dry and are exposed to aeolian onshore processes they can form extensive, region-wide parabolic dune systems (Goff et al., 2009). 
The study of modern tsunamigenic imprints carried out during posttsunami surveys (especially after the 2004 Indian Ocean, the 2010 Chilean or the 2011 Japanese tsunamis) contributes to extending our knowledge of tsunami coastal impacts and potentially providing present analogues to enhance the interpretation of those observed historically. These studies also allow to us refine the diagnostic criteria for detecting palaeotsunamis without the uncertainty on the generating mechanism and reducing preservation issues due to natural and anthropogenic disturbances. Fortunately, the study of the post-tsunami recovery of coastal systems is emerging, especially after the 2004 and 2011 tsunamis, and transforming our ability to re-asses and re-analyse the degree of coastal resilience to the impact of tsunamis. Meilianda et al. (2007) presented a quantitative budget of shoreline sediment fluxes before and immediately after a tsunami in Banda Aceh, Indonesia. They documented a widespread chaotic shoreline retreat caused by the tsunami. In the following six months and to the west of Banda Aceh town, they have observed shoreline accretion that induced $60 \%$ sediment recovery. In contrast, further erosion occurred on the northwest coast. In the same setting, Fagherazzi and Du (2008) showed that most of the morphological changes occurred in the shore-normal direction, with significant volumes of sand removed from coastal barriers (corresponding to 10 to $25 \mathrm{~cm}$-thick layers) but this amount of sediment returned after a short ( $<1$ year) period.

It is worth noting that the long-term changes (10-100 years) can mask tsunami imprints in the coastal landscape. On the other hand, these long-term changes can also add evidence of tsunami or other seismically-driven events, in agreement with the Seismic Staircase model proposed by Goff and McFadgen (2002) and Goff and Sugawara (2014). In this model, tsunami propagation, either directly by submarine fault rupture and/or earthquake-generated landslide, occurs immediately after the earthquake. This is followed by landslides and vegetation disturbances that also occurred at the time of the fault rupture, creating conditions for finer sediment availability which are transported rapidly to the coast, and later to the nearshore zone. This phase is followed by a post-event period of coastal dune building that can be used as a geomorphological imprint of a seismological driver of coastal change.

Geophysical techniques, such as Ground Penetrating Radar (GPR), have been used to explore the internal architecture of coastal barriers allowing the identification and mapping of facies resulting from different processes (Lindhorst et al., 2008; Costas and FitzGerald, 2011; Tamura, 2012; González-Villanueva et al., 2013). Several works have applied this tool to unravel the evolutionary history of coastal barriers and dunes and also to find signatures of abrupt events through the identification of erosive scarps, which are in turn interpreted as the imprints of the impact of past severe events (Buynevich et al., 2007). GPR has been used to reconstruct coastal progradation by mapping subsurface scarps and accretionary units, which in turn represent the morphological response of past erosional events and subsequent depositional phases, respectively (Buynevich et al., 2007). Furthermore, recent works have shown the potential of this technique deciphering the impacts of tsunamis through the analysis of the internal architecture of tsunami-generated deposits (Switzer et al., 2006; Koster et al., 2011, 2014) or imaging erosional imprints over coastal barriers (Rebêlo et al., 2013; Kain et al., 2014).

One key factor to achieve an understanding of (palaeo)tsunami events is the reliability of their sedimentological and geomorphological records, which in turn depends on the role played by three key variables: sediment availability, nature of the sediment, and pre-event coastal configuration. Moreover, it is important to use impacts of observed tsunamis as present-day analogues to interpret earlier ones, which facilitates the interpretation of morphological changes associated with these extreme marine inundations. The effort to understand the impact of (palaeo)tsunamis in the sedimentological record requires a broad view of the processes (e.g. different climates, hydrodynamic regimes, sediment budgets, etc.) in order to accurately assess the geomorphological consequences of tsunami wave impacts in diverse coastal systems.

Geomorphological studies of the effects of palaeotsunamis in coastal regions are scarce, regardless the coastal region addressed. This statement is true for the AD 1755 tsunami despite its relevance to Europe and in particular to SW Iberia.

In this work, specific geomorphological features that resulted from the AD 1755 tsunami on the Algarve coast are interpreted based on lithostratigraphy, GPR and dune/lowland morphology, and are compared with numerical modelling of tsunami overwash. This work aims to contribute to the study of tsunamigenic impacts and coastal system recovery in a region devastated by the strongest tsunami that has affected the coasts of Atlantic Europe in historical time. Moreover, we assess the maximum water level of the tsunami at the coast based on the correlation of the spatial distribution of the depositional signature with the elevation of erosional imprint identified within the internal barrier. Finally, with the same purpose in mind, tsunami wave modelling is conducted and validated with field data.

\section{Study area}

\subsection{Geology and hydrodynamic regime}

The southern Portuguese coastline (Fig. 1) presents a high degree of morphological asymmetry, mainly due to differences in the local geology. The central sector of the southern coastline (where the study areas are located- Fig. 1B) is cut in intensely karstified calcareous rocks forming cliffs that reach $40 \mathrm{~m}$ in height with steep slopes. In this coastal segment, streams and rivers have large basins flowing into rias, lagoons, estuaries and wide bays, with long sandy beaches frequently formed in front of the cliffs.

Tides along the Algarve coast range between $2.8 \mathrm{~m}$ (spring) and $1.3 \mathrm{~m}$ (neap) with a maximum tidal range of $3.5 \mathrm{~m}$ (i.e. reaching $1.8 \mathrm{~m}$ above mean sea level, msl). Taborda and Dias (1992) suggest a typical value of $+0.42 \mathrm{~m}$ surge for Lagos while maximum reported sea-level elevation during spring tides and severe storms can reach up to $2.15 \mathrm{~m}$ above $\mathrm{msl}$ (Esaguy, 1984). This region is dominated by a low energy wave regime with mean annual significant wave heights (Hs) slightly below $1 \mathrm{~m}$ with a period of $5 \mathrm{~s}$. Conversely, Hs of stormgenerated waves approaching from the SW during winter may reach values about of 3-4 m with periods of 7-8 s (Pessanha and Pires, 1981). Storm waves of lower heights and periods are generated by strong easterly winds throughout the year.

The Alcantarilha and Salgados lowlands are located in the central Algarve coast between Armação de Pera and Galé (Fig. 1B, C) and are connected by a $6 \mathrm{~km}$-long sand barrier. The continuity of the sand barrier is interrupted by ephemeral inlets at both the Alcantarilha and Salgados lowlands. These are related to the hinterland valleys and meet the ocean as outlets of intermittent streams: The Alcantarilha and Espiche Rivers, which, respectively, drain 204 and $41 \mathrm{~km}^{2}$ catchments, mostly developed over limestones, siltstones and sandstones (Moura et al., 2007). Nowadays, both lowlands are extensively silted up and their landward margins are occupied for agricultural and touristic uses.

The barrier consists of a reflective-intermediate sand beach and foredunes that reach a maximum elevation of $17 \mathrm{~m}$ above $\mathrm{msl}$. The barrier abuts against cliffs affecting soft detrital and carbonate Cenozoic rocks and covers Quaternary beach-rock and consolidated aeolianite deposits (cf. Moura et al., 2007). The densely vegetated dune field occupies an area of approximately $0.85 \mathrm{~km}^{2}$ and the profile of the frontal dunes roughly corresponds to an asymmetrical triangle, steeply sloping and sometimes scarped in the seaward direction (Pinto and Teixeira, 2002). The emerged sandy beach has an orientation varying from $E-W$ to NW-SE and has a width of 50 to $110 \mathrm{~m}$ (Pinto and Teixeira, 2002). Beach sediments are typically medium sands, although coarser and finer sand fractions can occur locally. 


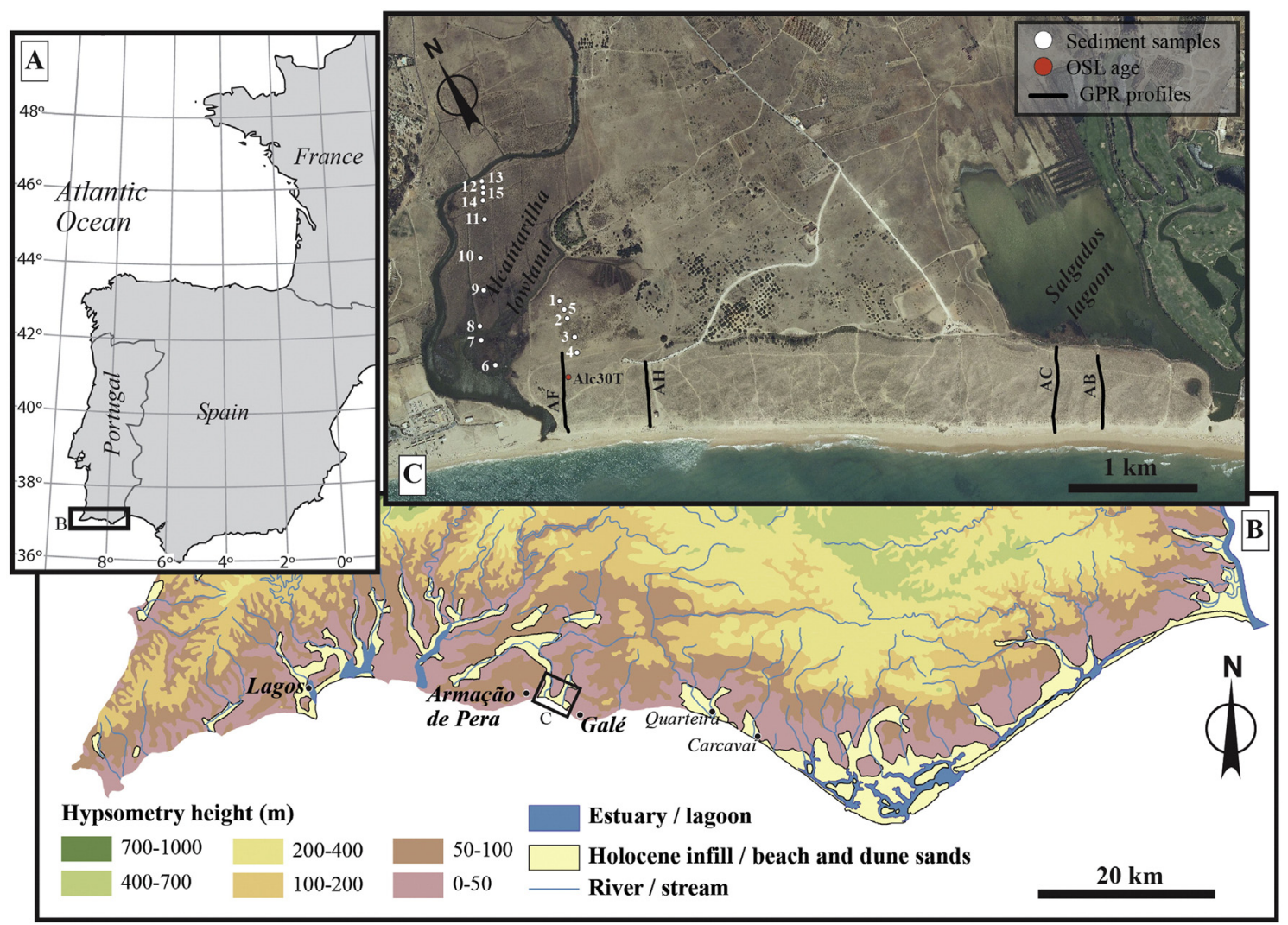

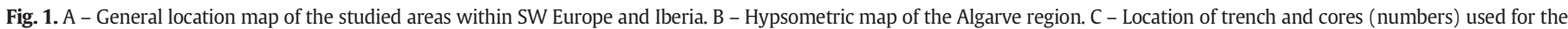

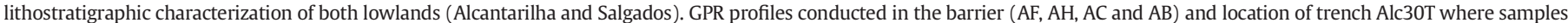
for OSL dating were collected.

\subsection{The $A D 1755$ tsunami in SW Portugal}

The AD 1755 tsunami inundation and associated deposits have been described in both the Alcantarilha and Salgados lowlands (Lopes, 1841; Costa et al., 2009, 2012; Dinis et al., 2010). Lopes (1841, page 290) describes the tsunami as follows: "In...Armação [a 17th century fishing settlement immediately west of Alcantarilha lowland], located in the beach $1 / 4$ of league from another village named Pera [ 1 Portuguese terrestrial league $=6172.836 \mathrm{~m}$ (Barreiro, 1838; Marques, 2001)] $(\ldots)$ the sea left one house standing (...) it rushed more than $1 / 2$ league inland, flooding everything, leaving salt water lakes in the lowlands, creating islands and drowning 84 people (...)".

In the Salgados lowland, the AD 1755 tsunami deposited a sandy layer that contrasts with the under- and overlying muddy sediments that represent the regular sedimentary regime. The deposit overlies an unconformity interpreted as an erosive contact with the underlying sediments (Costa et al., 2012). Micropalaeontological, microtextural and age constraining techniques indicated the AD 1755 tsunami as the most suitable candidate for the deposition of this unit. The spatial distribution of textural and geometric attributes of the tsunamigenic unit suggests that the waves entered the lagoon through the inlet and across the adjacent dunes (Costa et al., 2012). Observation of present-day morphology suggests that the tsunami overtopped a part of the barrier where dunes reach up to $10 \mathrm{~m}$ above msl. Moreover, the same authors used compositional analyses to identify dune and beach sediments as the most likely sediment sources of the tsunamigenic unit. In the Alcantarilha lowland, Dinis et al. (2010) described a sandy overwash fan attached to the leeward toe of the dune ridge just east of the present-day inlet. The fan thins and wedges out inland into the adjacent alluvial plain sediments. They attributed the fan's origin to localized overwash and erosion of the dune by the AD 1755 tsunami and constrained the run-up height in this area to $<10 \mathrm{~m}$ above msl.

\section{Methods}

\subsection{Dune morphology}

Vertical aerial photographs obtained from 1947 to 2010 with spatial scales ranging from 1:20,000 to 1:5000, have been used to document changes in dune morphology over the past 60 years and to search for possible tsunami and post-tsunami geomorphological features. Photographs were digitized and processed using ArcGISTM to produce georeferenced images. At least 20 landmarks were identified on each photograph and root mean square errors of $<2 \mathrm{~m}$ were accepted. The comparison and superimposition of successive corrected images were combined with topographic information (LiDAR airborne survey) to generate a dynamic visualization of erosive imprints, following Goff et al. (2009), and dune recovery trends. Delineation and characterization of the main erosive (scarps or pedestals) and other geomorphological features (bare sand, depositional lobe, rim dune or vegetation cover) were obtained by applying GIS techniques.

\subsection{Lithostratigraphy and age-estimation}

Sediment samples were obtained using box-corers on trench walls and hand-operated Edelman, gouge augers and a Van der Staay suction corer. Different facies were identified based on visual description of the sediment including colour identification, textural features, contact type between sediment units, lithology, presence of erosional features and macrofossil remains. Sampling locations were georeferenced and their elevation above msl determined using a DGPS RTK. Logs were plotted and 2D correlations were established. Additional chronological information in the form of previously published ${ }^{14} \mathrm{C}$ ages was used to complement interpretation of the Holocene stratigraphic sequence (Table 1). 
Table 1

Summary of Holocene radiocarbon ages published previously for the studied region (Schneider et al., 2010; Costa et al., 2012). For locations see Fig. 1.

\begin{tabular}{|c|c|c|c|c|c|}
\hline Core code & Laboratory code & Type of sample & Height $(\mathrm{m}, \mathrm{msl})$ & ${ }^{14} \mathrm{C}$ age, years BP & Calibrated age, $2 \sigma$ (years cal. BP) \\
\hline \multicolumn{6}{|c|}{ Quarteira estuary (Schneider et al., 2010) } \\
\hline PO1-5 & Erl-11847 & Charcoal & -0.19 & $2979 \pm 42$ & $3006-3324$ \\
\hline PO1-5 & UTC-11357 & Shell & -0.52 & $3977 \pm 38$ & $4290-4530$ \\
\hline PO1-5 & UTC-11358 & Charcoal & -1.82 & $4619 \pm 42$ & 5070-5470 \\
\hline PO1-5 & UTC-11360 & Shell & -2.37 & $4763 \pm 39$ & $5330-5590$ \\
\hline \multicolumn{6}{|c|}{ Carcavai estuary (Schneider et al., 2010) } \\
\hline VdL PB2 & Erl-9832 & Charcoal & 2.09 & $306 \pm 59$ & $154-500$ \\
\hline VdL PB2 & Beta-239918 & Charcoal & 1.53 & $160 \pm 40$ & $0-290$ \\
\hline VdL PB2 & Beta-245051 & Charcoal & 1.15 & $990 \pm 40$ & $800-960$ \\
\hline VdL PB2 & Beta-245052 & Charcoal/charred material & 0.49 & $1500 \pm 40$ & $1410-1610$ \\
\hline VdL PB2 & Erl-9833 & Charcoal & -0.52 & $2351 \pm 41$ & 2213-2679 \\
\hline VdL PB2 & Beta-245053 & Cone scale & -0.61 & $2520 \pm 40$ & $2470-2740$ \\
\hline VdL PB2 & Erl-11849 & Charcoal & -0.63 & $2512 \pm 43$ & $2369-2747$ \\
\hline VdL PB2 & Beta-239919 & Charred material & -0.93 & $2730 \pm 50$ & $2750-2950$ \\
\hline VdL PB2 & Beta-245058 & Charcoal & -1.09 & $2570 \pm 40$ & $2540-2760$ \\
\hline VdL PB2 & Beta-245059 & Charcoal & -1.35 & $3070 \pm 40$ & $3210-3370$ \\
\hline VdL PB2 & Erl-11850 & Charcoal/charred material & -1.64 & $5486 \pm 57$ & 6189-6403 \\
\hline VdL PB2 & Erl-9834 & Charcoal/charred material & -1.68 & $5468 \pm 75$ & 6017-6409 \\
\hline VdL PB2 & Erl-11851 & Charcoal/charred material & -2.11 & $5587 \pm 48$ & 6293-6467 \\
\hline VdL PB2 & Beta-245056 & Charcoal/charred material & -4.16 & $6210 \pm 40$ & $7000-7250$ \\
\hline VdL PB2 & Beta-245057 & Charcoal/terrestrial plants & -5.11 & $7300 \pm 40$ & $8010-8180$ \\
\hline \multicolumn{6}{|c|}{ Quarteira (Schneider et al., 2010) } \\
\hline Tsunami & Beta-259194 & Charcoal & Tsu1 above & $480 \pm 40$ & $490-550$ \\
\hline Tsunami & Beta-259195 & Charcoal/graphite & Tsu1 below & $2250 \pm 40$ & $2150-2340$ \\
\hline Tsunami & Beta-259196 & Charcoal & Tsu2 above & $2450 \pm 40$ & $2350-2720$ \\
\hline Tsunami & Beta-259197 & Charcoal & Tsu2 below & $2710 \pm 40$ & $2750-2870$ \\
\hline \multicolumn{6}{|c|}{ Salgados lagoon (Costa et al., 2012) } \\
\hline SG_LV12 & Beta-275686 & Organic sediment & 0.65 & $980 \pm 40$ & 790-960 \\
\hline SG92 & Beta-278062 & Organic sediment & 0.82 & $1300 \pm 40$ & $1170-1300$ \\
\hline SG37 & Beta-278060 & Organic sediment & 0.74 & $1380 \pm 40$ & $1270-1340$ \\
\hline SG_LV7 & Beta-275685 & Organic sediment & 0.68 & $1420 \pm 40$ & $1280-1380$ \\
\hline SG39 & Beta-278061 & Organic sediment & 0.69 & $1610 \pm 40$ & $1400-1570$ \\
\hline SG1 & Beta-248209 & Organic sediment & -1.04 & $2820 \pm 40$ & $2850-3030$ \\
\hline SG6 & Beta-248211 & Organic sediment & -1.61 & $4710 \pm 40$ & $5320-5580$ \\
\hline SG46 & Beta-241181 & Organic sediment & -1.39 & $4760 \pm 40$ & $5330-5590$ \\
\hline SG5 & Beta-248210 & Organic sediment & -1.52 & $4850 \pm 40$ & $5480-5650$ \\
\hline SG47 & Beta-248212 & Organic sediment & -1.37 & $4940 \pm 40$ & $5600-5740$ \\
\hline SG1 & Beta-241182 & Organic sediment & -2.93 & $5920 \pm 50$ & $6650-6880$ \\
\hline
\end{tabular}


These ages were obtained in the Quarteira and Carcavai estuaries (Schneider et al., 2010) and in the Salgados lagoon (Costa et al., 2012). In this work, additional ages for the sand barrier were obtained from Optically Stimulated Luminescence (OSL) dating (Table 2).

OSL dating was applied to provide a numerical chronology at the Alc30T site (Fig. 1). OSL measures the time that has elapsed since the last time quartz or feldspar grains were exposed to daylight. Nine samples for OSL dating were collected by hammering PVC pipes into sediments exposed in a dug trench (see Table 2 for sampling depths). Only the middle part of the sample was used for OSL measurements; the outer part was used for radionuclide analysis using gamma spectroscopy, following Murray et al. (1987). Laboratory processing of the middle part of the tube consisted of a series of conventional sample preparation procedures (e.g. sieving, acid leaching and oxidation with $10 \% \mathrm{HCl}, 10 \% \mathrm{H}_{2} \mathrm{O}_{2}, 40 \% \mathrm{HF}$ ) under subdued light conditions. The extracted $180-250 \mu \mathrm{m}$ quartz grains were mounted as multi-grain subsamples on stainless steel cups and measured in a Risø TL/OSL reader equipped with blue $(470 \mathrm{~nm})$ and infrared $(875 \mathrm{~nm})$ LEDs and a calibrated beta source. The purity of the quartz extracts was confirmed by an OSL IR depletion ratio test following Duller (2003). Equivalent dose $\left(D_{e}\right)$ values were measured using a SAR protocol using blue light stimulation for $40 \mathrm{~s}$ at $125^{\circ} \mathrm{C}$. The preheat treatments of the natural/regenerative dose and test dose were $180^{\circ} \mathrm{C} / 10 \mathrm{~s}$ and $160^{\circ} \mathrm{C}$, respectively. These low preheat temperatures avoid the risk of a thermally transferred dose (e.g. Madsen and Murray, 2009). At the end of each SAR cycle the quartz grains were stimulated at $280^{\circ} \mathrm{C}$ for $40 \mathrm{~s}$ with blue light to minimise recuperation. Signals for dose calculation were derived from the first $0.8 \mathrm{~s}$ of the decay curve less a background from the 1.4-2.4 s interval, and a linear fit was used to derive the $\mathrm{D}_{\mathrm{e}}$. To confirm the suitability of this measurement protocol a dose recovery test was carried out. Twentyfour aliquots (three aliquots per sample, except sample 105232) were bleached twice with blue light for $40 \mathrm{~s}$ at room temperature (separated by a 10.000 s pause). They were then given a dose of $4.9 \mathrm{~Gy}$ and this dose was measured using the abovementioned SAR protocol. The average 'measured' to 'given' dose ratio is $0.977 \pm 0.015$, indicating that the chosen SAR protocol is suitable for measuring a dose given prior to any heat treatment. The unweighted average equivalent doses (no aliquots were rejected due to poor recycling or high recuperation values) and corresponding standard errors were calculated and used for age determination.

The total dose rates were calculated from the radionuclide activities using the conversion factors from Olley et al. (1996) and assuming low life-time average water contents of $2-6 \%$. The water content of sand samples was determined by weighting controlled volumes of sand before and after oven-heating at $60^{\circ} \mathrm{C}$. Field observation shows that sand samples have been collected well above the regional water table and considering the high porosity and permeability of the dune sand these values were considered representative of the long-term average water content. The cosmic-ray dose rate contribution was calculated following Prescott and Hutton (1994).

\subsection{Ground penetrating radar (GPR)}

GPR is a non-destructive geophysical reconnaissance tool for imaging the subsurface based on the propagation and reflection of transmitted electromagnetic pulses. GPR record changes in the dielectric properties of sediments primarily caused by changes in water content, mineralogy, grain size, organics, and sedimentary fabric (Topp et al., 1980; Van Dam and Schlager, 2000). The strength of the reflected signal is approximately proportional to the difference in dielectric constants at sediment interfaces (Davis and Annan, 1989). Attenuation of the electromagnetic radar signals by saltwater confined the extent of this study to the emerged section of the sandy barrier (back-beach and dunes). The penetration depth and resolution of the reflection data are both functions of wavelength and dielectric constant values, which in

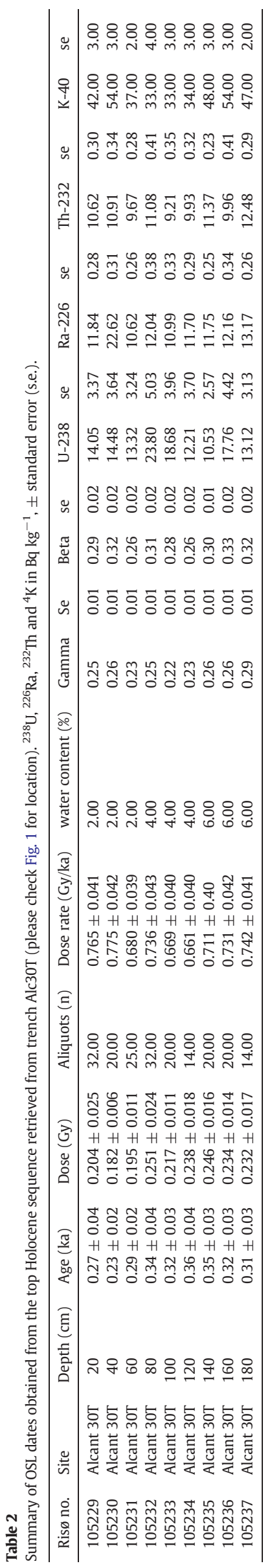


turn are mainly controlled by the water content of the materials (Davis and Annan, 1989; Daniels, 1996; Grant et al., 1998; Rodríguez Santalla et al., 2009). In general, reflections from the interior of aeolian dunes are produced principally by changes in moisture (Van Dam and Schlager, 2000; Van Dam, 2001; Schenk et al., 2009) and concentrations of heavy minerals (Dougherty et al., 2004; Moore et al., 2004). Images of the subsurface were acquired using an Ingegneria Dei Sistemi-Ground Penetrating Radar (IDS-GPR) system RIS MF Hi-Mod \#1 equipped with a dual frequency antenna (200 and $600 \mathrm{MHz}$ ). A total of four cross-shore, $250 \mathrm{~m}$-long GPR profiles were surveyed across the Alcantarilha-Salgados sand barrier, from the upper beach towards the backbarrier area (Fig. 1C). The location of the profiles was selected considering the mean elevation of the barrier. Maximum penetration (around $8 \mathrm{~m}$ below surface) was achieved using the $200 \mathrm{MHz}$ antenna. Low penetration was due to the attenuation of the electromagnetic waves by the presence of salt water infiltrations from the beach.

The GPR was synchronized to a GPS -RTK-system in order to obtain the topographical information for static correction during the processing of the radargrams. Raw data were processed using the program package Reflex-Win Version 5.0 .5 by Sandmeier Software. Data processing included application of filters and gains, velocity profile estimate, migration and static corrections. An average subsurface velocity of $0.13 \mathrm{~m} / \mathrm{ns}$ was estimated using the interactive hyperbola-adaptation method and is a typical velocity for dry sand.

\section{4. $1 D$ simulation of the impact of the tsunami over the coastal barrier}

The model used in this study was XBeach (Roelvink et al., 2009), originally developed as a two-dimensional process-based storm impact model but shown to be applicable in a range of other conditions, including tsunami impacts (e.g. Li et al., 2012; Li and Huang, 2013). The latter includes extensive validation of modelling results on the morphological impact of a tsunami based on experiments carried out by Young et al. (2010). Good agreement with flood extent was found for XBeach using a combination of non-linear shallow water equations and an advection-diffusion equation for sediment and dynamic bed updating.

A recently implemented functionality in XBeach, viz. a one-layer non-hydrostatic model, following the formulations by Stelling and Zijlema (2003); Zijlema and Stelling (2005, 2008) and implemented by Smit et al. (2013), is applied in the present study. This model configuration includes wave dispersion, which may have effects on the propagation of tsunamis, especially around islands or large topographic variations.
To verify that the version applied reproduces the findings of $\mathrm{Li}$ and Huang (2013), a test from Young et al. (2010), viz. ST60, was simulated. Results from the experiment are compared with those obtained by XBeach in Fig. 2, showing a good agreement, with a dominantly erosive behaviour but including a small landward berm-like deposition.

The large-scale tsunami generation and propagation is modelled based on the bathymetry and initial conditions used in Baptista et al. (2011a) and provided by Joaquim Luis (University of Algarve). The model has a $1 \mathrm{~km}$ by $1 \mathrm{~km}$ resolution, which is deemed adequate to resolve the shape of the tsunami approaching the southwestern Portuguese coast. Fig. 3 shows the initial water level disturbance and the tsunami pattern at the time of arrival at the $100 \mathrm{~m}$ depth contour, both for the overall model domain and for a zoom of the southwestern coast. All XBeach model boundaries were Riemann boundaries, allowing the waves to leave the domain without visible disturbances. Tsunami propagation was also simulated using the COMCOT-Lx code (Baptista et al., 2011b). Results were compared for control points near Lisbon, between the COMCOT-Lx model and Xbeach, showing a relatively good correspondence.

The depth of $100 \mathrm{~m}$ was chosen to couple the coarse-grid overall model with a detailed 1D cross-section model cutting across the dune profile at the Alcantarilha lowland at the location of the GPR transect AF (Fig. 1) in order to reproduce the impact of the tsunami over the sand barrier. Because the shape of the sand barrier when the tsunami impacted the coast is not known, different simulations have been running changing the morphology of the cross-shore profile. Three profiles were created (Fig. 4); Test-01 represents the present-day barrier profile, Test-02 represents a profile similar to the present day, but with lower topography, and Test-3 represents a profile with a lower crest elevation and slope within the foreshore and foredune.

The $100 \mathrm{~m}$ water depth was chosen to be sufficiently far away from the coast to allow the tsunami wave to steepen and turn into a bore within the detailed model domain. A weakly reflective boundary condition was generated with an input wave based on the incident water level and crossshore velocity variation; it was verified that these matched in the overall and detailed models. In Fig. 5 the water levels at the $100 \mathrm{~m}$ contour are shown to match well in both models. Note that the high peak in the detailed model occurs at approx. $3500 \mathrm{~s}$; this represents the reflected wave coming back from the beach. The mean water level was taken to be $+1.0 \mathrm{~m}$ above msl, based on a reconstruction of the astronomical tide at Lagos for the date of the tsunami, with high tide around 11 a.m.

The model grid was generated based on the cross-shore profile extracted from the detailed bathymetry/topography, with grid sizes varying from $50 \mathrm{~m}$ in deep water to $2 \mathrm{~m}$ across the dune profile. The duration
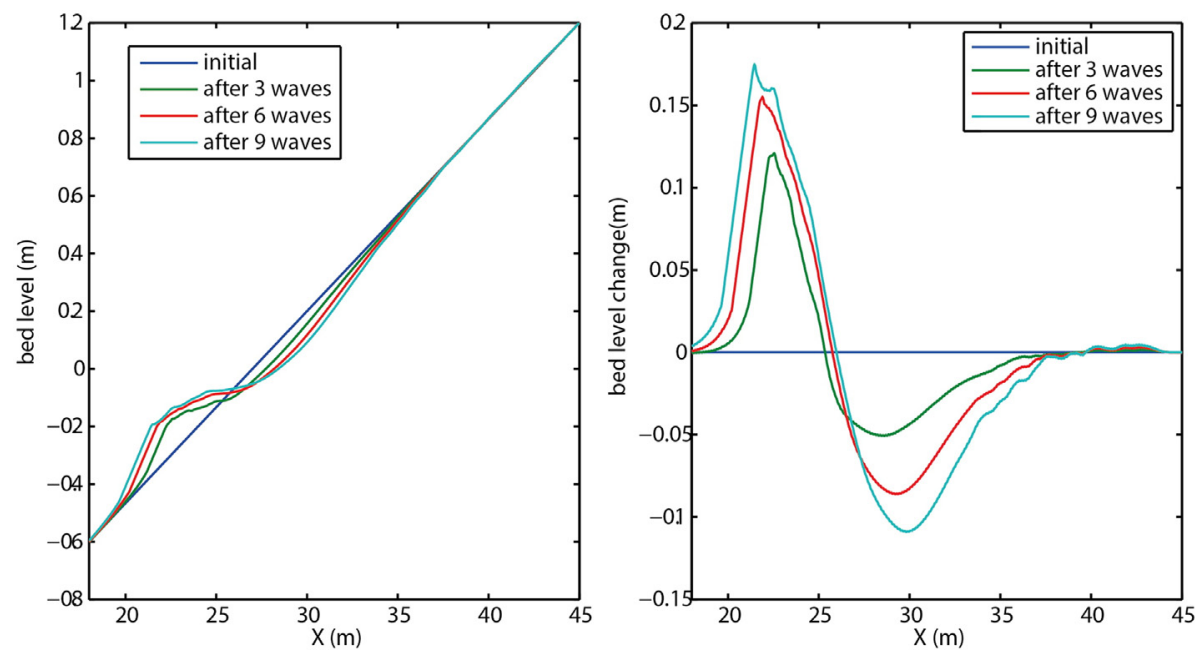

Fig. 2. Bed evolution (left) and erosion/sedimentation changes as simulated by XBeach (right). 

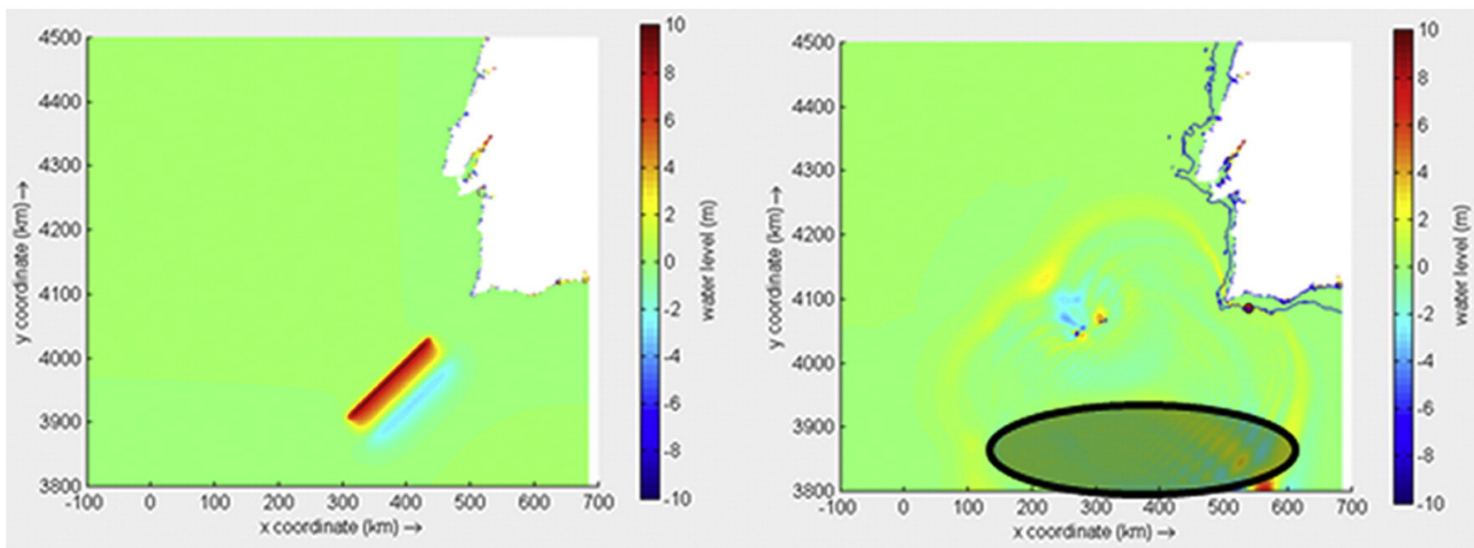

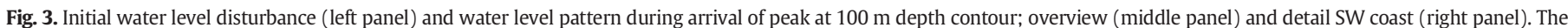

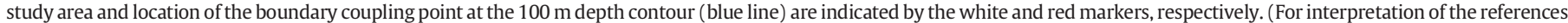
to colour in this figure legend, the reader is referred to the web version of this article.)

of the simulations was $4500 \mathrm{~s}$. The largest impact took place during the first wave, which hit the $100 \mathrm{~m}$ water depth contour approx. $21 \mathrm{~min}$ after tsunami initiation and arrived at the coast after approx. 40 min.

\section{Results}

\subsection{Dune morphology}

Aerial photographs display a notable increase in vegetation cover between 1947 and 2010, which represents the most significant change in the study area. The earliest images (1947, Fig. 6) show well-
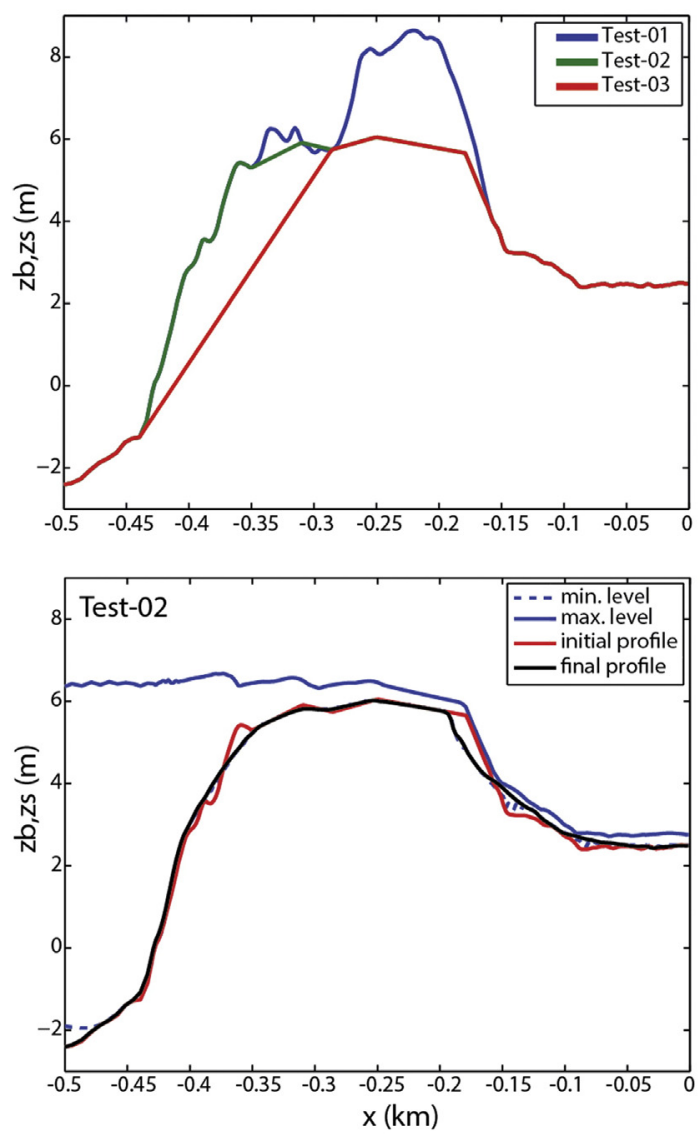

developed erosive aeolian features (blowouts and/or parabolic dunes) that developed prior to 1947. The depositional lobes associated with the blowouts and parabolic dunes are oriented to the NE, suggesting dominant S-SW winds. The interpretation of the aerial photographs suggests that parabolic dunes remained inactive between 1947 and 2010, allowing vegetation growth (Fig. 6). Erosive scarps at the dune foot were identified and used as indicators of shoreline changes. During the period between 1947 and 2010 no significant changes in shoreline position were observed.

The dune field appears fragmented showing features that resemble the pedestals described by Goff et al. (2009), as well as a set of
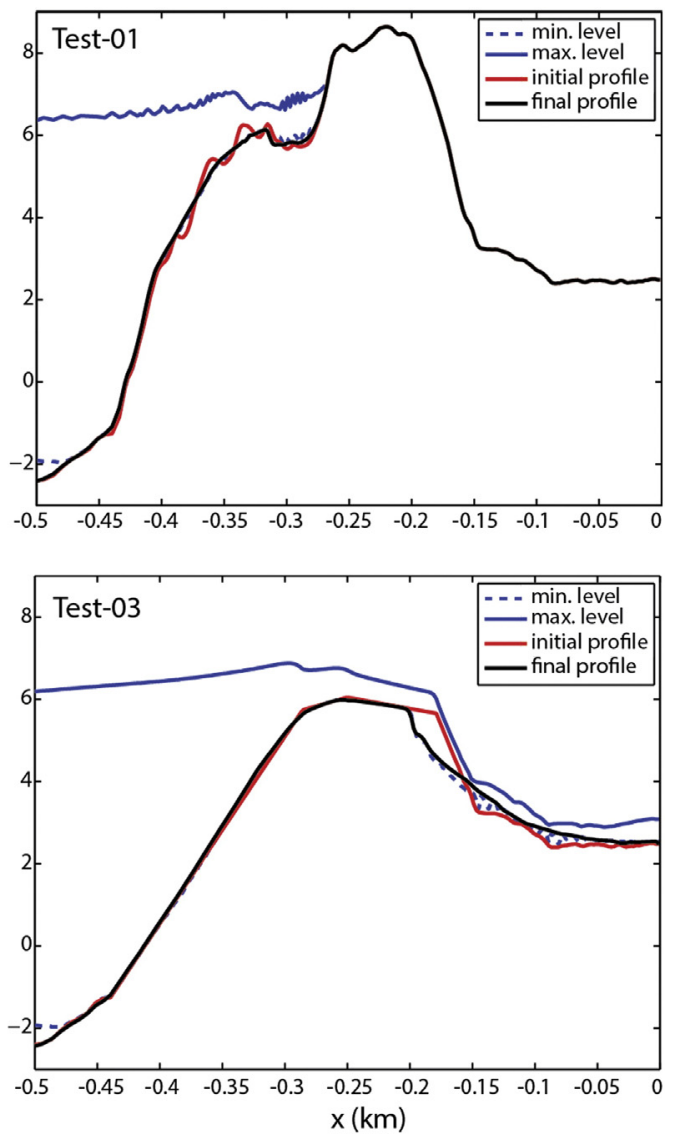

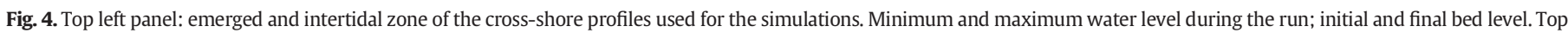
right panel: existing profile. Bottom left panel: possible lower profile with crest height at $6 \mathrm{~m}$ above msl. Bottom right panel: lower crest height and mild $(\sim 1 / 30)$ slope. 


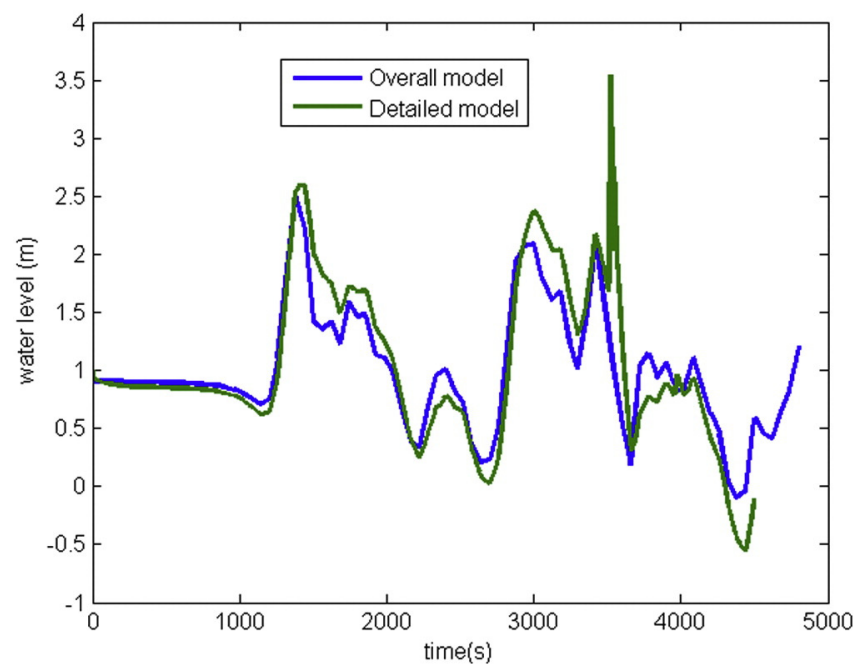

Fig. 5. Water level time-series at the $100 \mathrm{~m}$ depth contour in overall and detailed model.

inner scarps and intact landward dunes in the central area (Fig. 6). These features can be clearly identified within the aerial photograph of 1947 but they are obscured by the vegetation cover in later images. The aerial photography analysis was supported by LiDAR data, allowing the definition of the dimensions of the identified features (i.e. pedestals and inner scarps). Pedestals surfaces range from 50 to $600 \mathrm{~m}^{2}$, with the tops reaching elevations between 6.5 and $16.4 \mathrm{~m}$ above msl. The length of the inner scarps range from 30 to $150 \mathrm{~m}$ with a vertical offset between 2 and $5 \mathrm{~m}$. The higher slopes were observed in the central area.

\subsection{Lithostratigraphy and chronology}

Coring surveys of the Alcantarilha and Salgados lowlands were undertaken to understand their long-term evolutionary trajectory and also to search for traces of tsunami deposits. Trenches were excavated and hand-driven cores obtained in the coastal sector and nearby floodplain to study its sedimentology, lithostratigraphy and geometry. The detailed age-models of the lowland sequences were summarized by Schneider et al. (2010); Dinis et al. (2010) and Costa et al. (2012) and do not include our OSL dates (from the dune) given in Table 2. Here, we compile all available information from the literature and new observations to present the Holocene stratigraphic sequence (formed since approx. 7000 cal. yr BP, see summary in Fig. 8) for both sites organized in 7 facies associations, which are briefly described below (Fig. 7A, B and Tables 1 and 2):

Facies F1 - Sandy lagoonal deposits - this facies association corresponds to (mostly) greyish sands with marine shell fragments and less abundant clay laminae. Most of the sediment showing facies F1 accumulated in an essentially shallow environment open to marine influence, preceding the drastic deceleration in the rate of sea-level rise around 6000 to $7000 \mathrm{cal}$. yrs BP. The origin of this facies was previously associated with the Holocene transgression in the Algarve (see Schneider et al., 2010 and Costa et al., 2012 for further details).

Facies F2 - Tidal flat deposits - F2 essentially consists of yellowish to greyish medium to fine sand containing marine shell (bivalves) fragments, and exhibiting normal grading. Sand is intercalated with numerous muddy laminae. An age range of approximately 1500 to $3000 \mathrm{cal}$. yrs BP was suggested for this facies by Costa et al. (2012).

Facies F3 - Alluvial plain/muddy lagoon deposits - this is the dominant facies association in the depositional record of both lowlands. F3 is composed of brownish silt and clay material of terrigenous source that becomes darker to the top/surface. It corresponds to recent and to
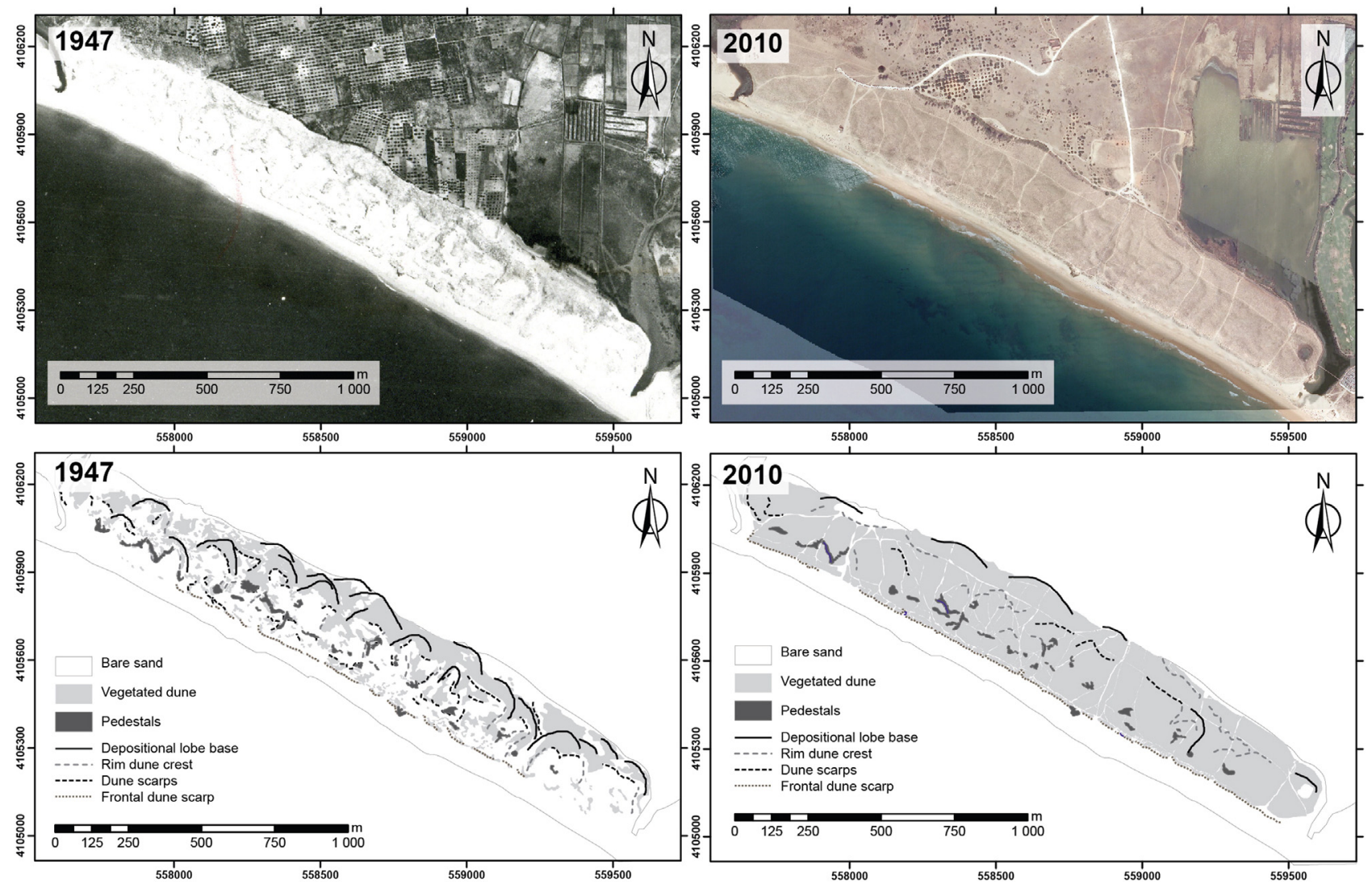

Fig. 6. Geomorphological interpretation of Alcantarilha-Salgados lowlands and sandy barrier. The reference system used was WGS84, UTM zone 29N. 

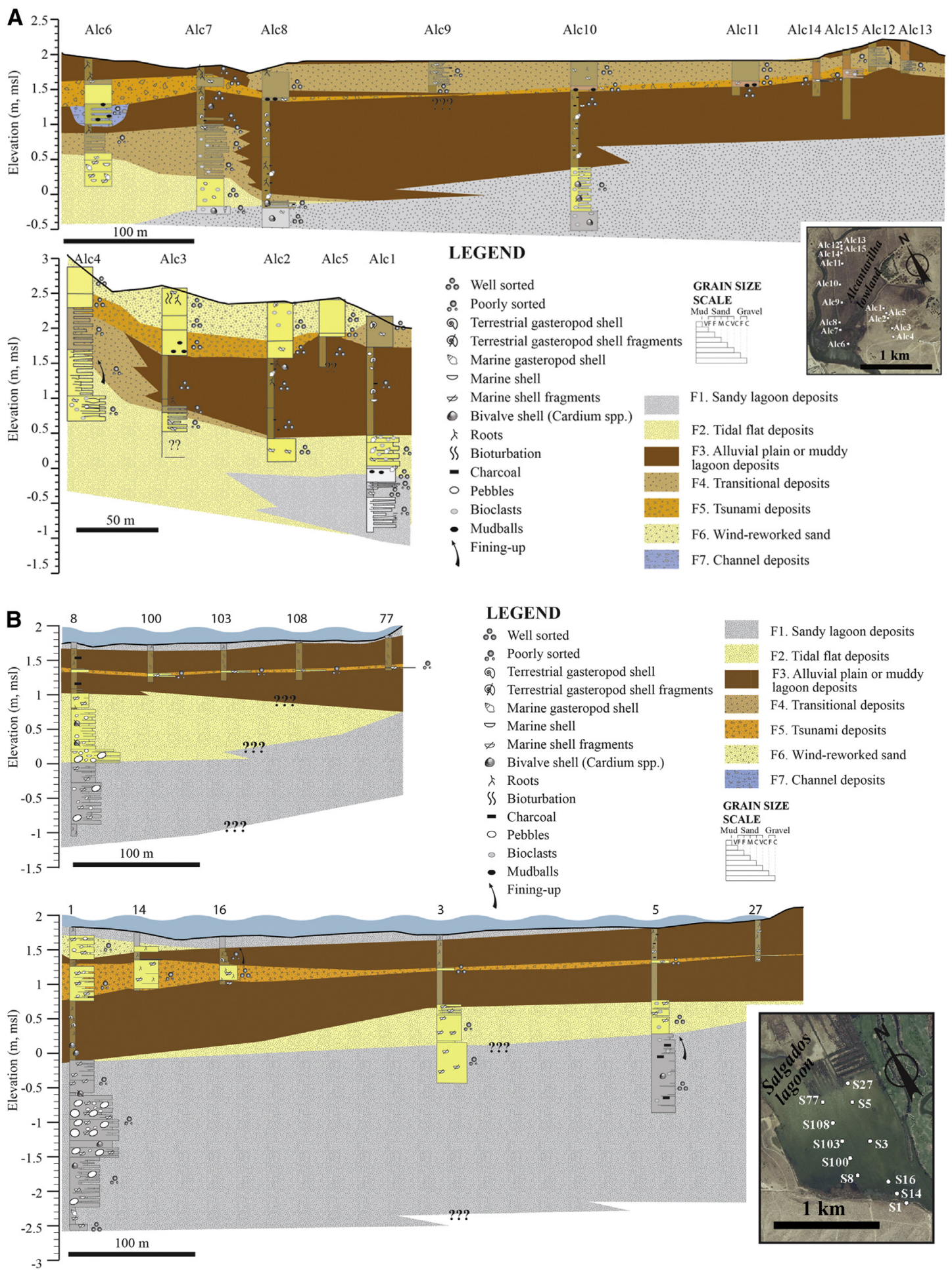

GRAIN SIZE SCALE Ud Sand Grave
IVFFMCVFC
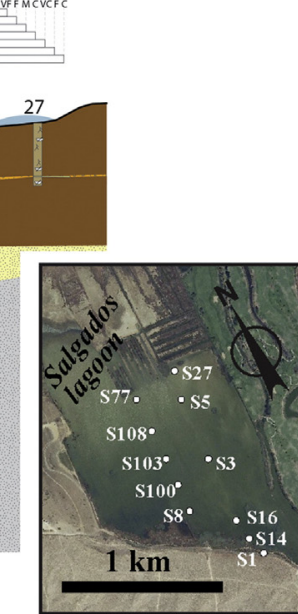

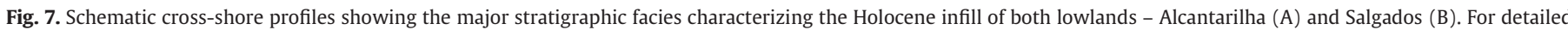
characterization of the facies please see text.

the present-day sediments across most of the lowlands subject to occasional flooding. Sediments of facies F3 have an average thickness of approximately $0.8 \mathrm{~m}$ and have been deposited in progressively lowerenergy conditions favoured by the presence of the barrier.

Facies F4 - Transitional (pedogenetic) deposits - only identified at the Alcantarilha lowland and with a very limited inland extent (sampled in both cross-sections illustrated in Fig. 7A). This facies consists of brownish poorly sorted, sandy silt, with terrestrial gastropod shell fragments and abundant calcium carbonate precipitates (caliche) that form irregular concretions or accumulate in pores within the sediment, hardening and imprinting a whitish colour to the host materials. Occasionally, this facies overlies facies F5 (Fig. 7A - cores 8 to 13) but it also develops in other stratigraphic positions. This pedogenic facies developed under dry weather conditions, favouring precipitation of calcium carbonate and the formation of caliche in relation with interstitial water.

Facies F5 - Tsunami deposits - they mostly consist of a laterally extensive layer of (marine) shell-rich sand usually free of mud, which ramps and thins landwards, displaying an erosive base and a sharp 


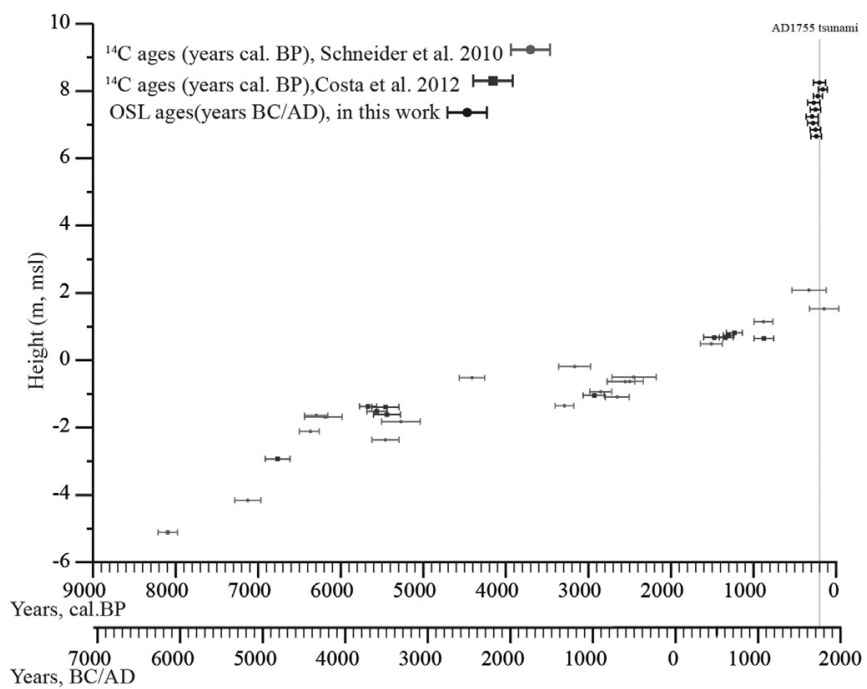

Fig. 8. Chronological framework of the regional Holocene sedimentation based in previously published radiocarbon dates (Schneider et al., 2010 and Costa et al., 2012) and new OSL dates.

upper boundary. This facies has a marked marine signature, as shown by its foraminiferal content (see Costa et al., 2012; Quintela et al., 2016). It is essentially composed of medium to fine sands, which contrasts markedly with the under- and overlying finer-grained lithofacies. It extends around $850 \mathrm{~m}$ inland. The sediment becomes finer and its thickness decreases inland until it wedges out and can no longer be macroscopically identified in trenches and cores. The general altitude of the basal contact rises gradually inland even though this facies varies laterally in terms of its thickness and sedimentary characteristics. Several centimetre-sized mud rip-up clasts from the underlying unit were identified in sediments with facies F5 always more noticeable and abundant close to the base of the tsunami layer (Costa et al., 2012). Linear extrapolation of sedimentation rates obtained from vertical profiles of ${ }^{210} \mathrm{~Pb}$ and ${ }^{137} \mathrm{Cs}$ in the sedimentary sequence allows association of this facies with the AD 1755 tsunami (Costa et al., 2012).

Facies 6 - Wind-reworked sand - these deposits are confined to the eastern and seaward margin of the cross-section of Alcantarilha (immediately adjacent to the leeward side of the dune) and they formed after the emplacement of a sandy fan that forms a prominent (though spatially restricted) geomorphological feature extending into the alluvial plain (as described in Dinis et al., 2010). It is composed of fine to medium, well sorted, sand and its presence inland is limited to a few hundred meters. The association of this facies with the AD 1755 event has been proposed before (Dinis et al., 2010) based on the morphology and singularity of the washover fan in this coastal sector. The fan is roughly ellipsoidal, $\sim 200 \mathrm{~m}$ wide and $\sim 300 \mathrm{~m}$ elongated parallel to the shoreline, rising 0.9-1.2 $\mathrm{m}$ above the surrounding floodplain surface with its boundaries visible in aerial photos (Fig. 6). Its lower boundary is undulating and marked by the textural contrast between sand (fan) and underlying mud (alluvial).

The multi-grain OSL ages for the Alc30T site below $60 \mathrm{~cm}$ (samples 105,232-37) overestimate the known age of the tsunami deposit by several tens of years (Table 2). The upper three samples $(20-60 \mathrm{~cm}$ depth) represent the deposition of well-bleached aeolian sand while the underlying samples exhibit the above-mentioned overestimation.

Facies 7 - Channel deposits - Only present in very narrow sections of the lowlands. For example, in core 6 (Fig. 7A) a fluvial channel was noted in the trench. These channels (either natural or anthropogenic) cut through and disturb some of the sediments discussed above.

\subsection{Ground penetrating radar}

The GPR profiles were surveyed across the coastal barrier through elevations that ranged between 3 and $10 \mathrm{~m}$ above msl. Lower elevations corresponded to the present-day upper beach, inter-dune depressions and back-barrier area, while higher elevations were reached when profiles crossed the crests of parabolic dunes and dune ridges. All GPR lines document a highly complex internal architecture dominated by unconformity surfaces separating well defined radar packages. Previous GPR data acquired in the coastal barrier by Moura et al. (2007) confirm lateral discontinuity and elevated complexity within the internal barrier stratigraphy.

Despite this complexity, some general patterns can be delineated allowing for a spatial and temporal correlation of GPR units between different profiles. Indeed, the same number of GPR units has been identified within every profile, numbered from 1 to 7 , following a chronological criterion (unit 1 corresponds to the older unit), finding a good correspondence between profiles. All profiles are dominated by radar packages (hereafter also designated by Units) consisting of landward-dipping reflections of variable amplitude (e.g. Unit 4 in profile AF, Fig. 9). The radar packages are about $100 \mathrm{~m}$ long (cross-shore section) and about $6 \mathrm{~m}$ thick. Internally, the packages consist of parallel clinoforms with foreset beds dipping between 5 and $12^{\circ}$, truncated topset and preserved bottom set beds. These radar packages are

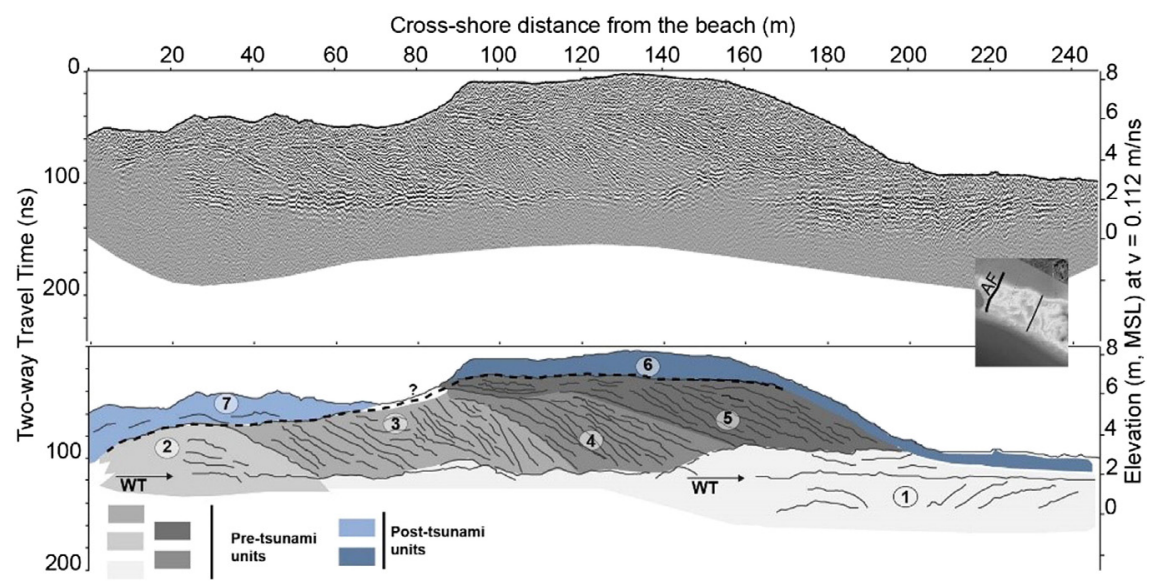

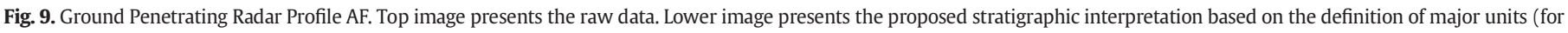

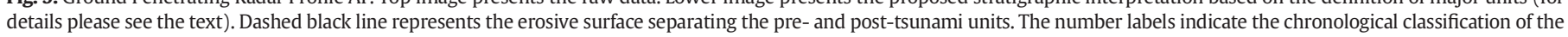
identified units labels. 


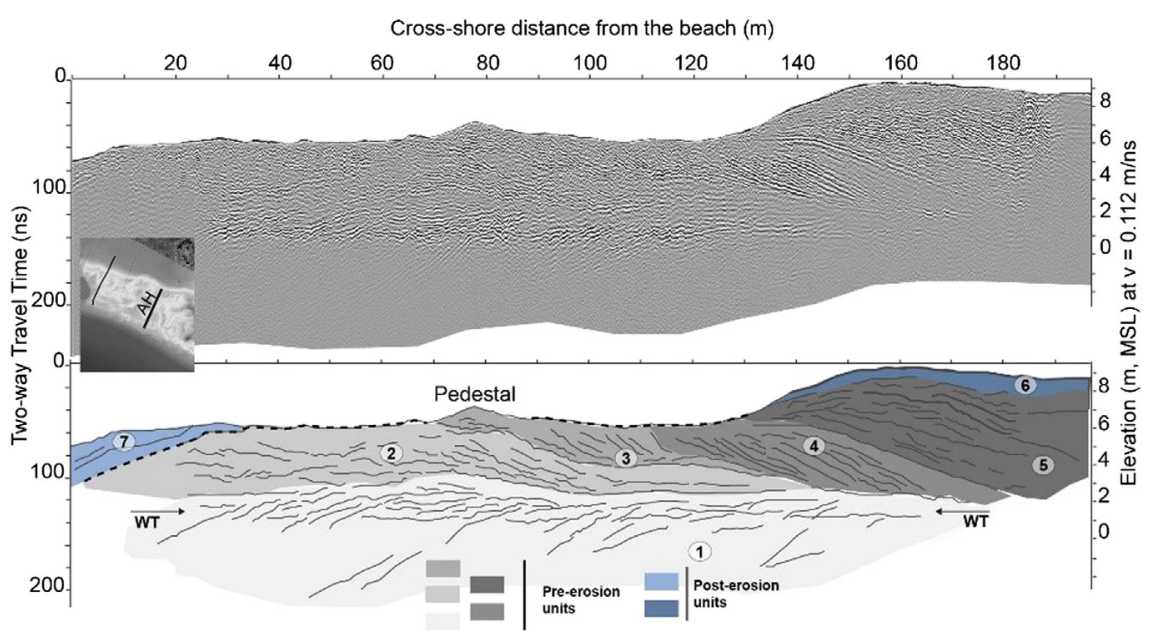

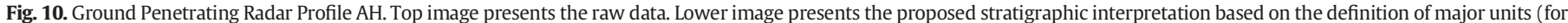

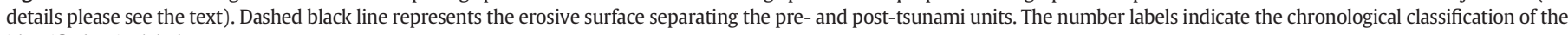
identified units labels.

interpreted here as units of aeolian deposits and indicate the onset of successive pulses on transgressive dunes moving landward.

These aeolian packages appear around $2 \mathrm{~m}$ above msl, overlaying a sub-horizontal surface that may represent the watertable (Figs. 9, 10 profile $\mathrm{AF}$ and $\mathrm{AH}$ ) or sediments of contrasting grain-size or compositions in the case of sub-horizontal high amplitude reflections located below $2 \mathrm{~m}$ above msl (e.g. Unit 1 in profile AC, Fig. 12 profile AC). Alternatively, these radar packages may overlay other radar facies characterized by undulating sets of cross laminae dominated by convex-up configurations (e.g. Unit 2 in profile AH, Fig. 10), which can be compared to the type of radar facies defined as bio-topographic accumulation by Bristow et al. (2000). The latter are interpreted as accretionary mounds around hummocks of vegetation frequently found within foredunes. The latter aeolian deposits overlay radar facies characterized by complex-sigmoidal to tangential reflections dipping seaward (e.g. Unit 1 in profile AH, Fig. 10). Gentle reflections are truncated seaward by steeply dipping reflections. Topset facies are interpreted as backshore sedimentation whereas steep reflections may represent erosive events responsible for truncating the first through the formation of beach or dune toe scarps (Costas and FitzGerald, 2011).

\subsubsection{Profile $A F$, stratigraphy and interpretation}

Profile AF is located in the vicinity of the Alcantarilha inlet (Fig. 9) and it is dominated by radar packages with landward-dipping reflections, suggesting the occurrence of at least three events of transgressive dune formation and landward migration (Units 3 to 5, Fig. 9). The latter appear to have migrated inland rolling over a package of sub-horizontal to wavy sediments interpreted as foredune and upper beach deposits, suggesting the preservation of a former foredune (Unit 2, Fig. 9). Landward, in the back-barrier area, oblique reflections dipping seaward support the presence of a former beach and document the seaward progradation of the shoreline towards its present position over time leaving a surface on top of which transgressive dunes migrated landward. The entire emerged barrier, including all transgressive aeolian units, is truncated by a surface located around 6-7 $\mathrm{m}$ above msl that gently dips seaward (Fig. 9). Within the landward half of the profile, this surface is partially overlaid by a $2 \mathrm{~m}$-thick unit without a clear internal configuration represented by massive deposits laid down during a rapid depositional event (Unit 6, Fig. 9). Conversely, the same surface within the seaward half of the profile is overlain by undulating sets of cross-laminae dominated by convex-up configurations, suggesting

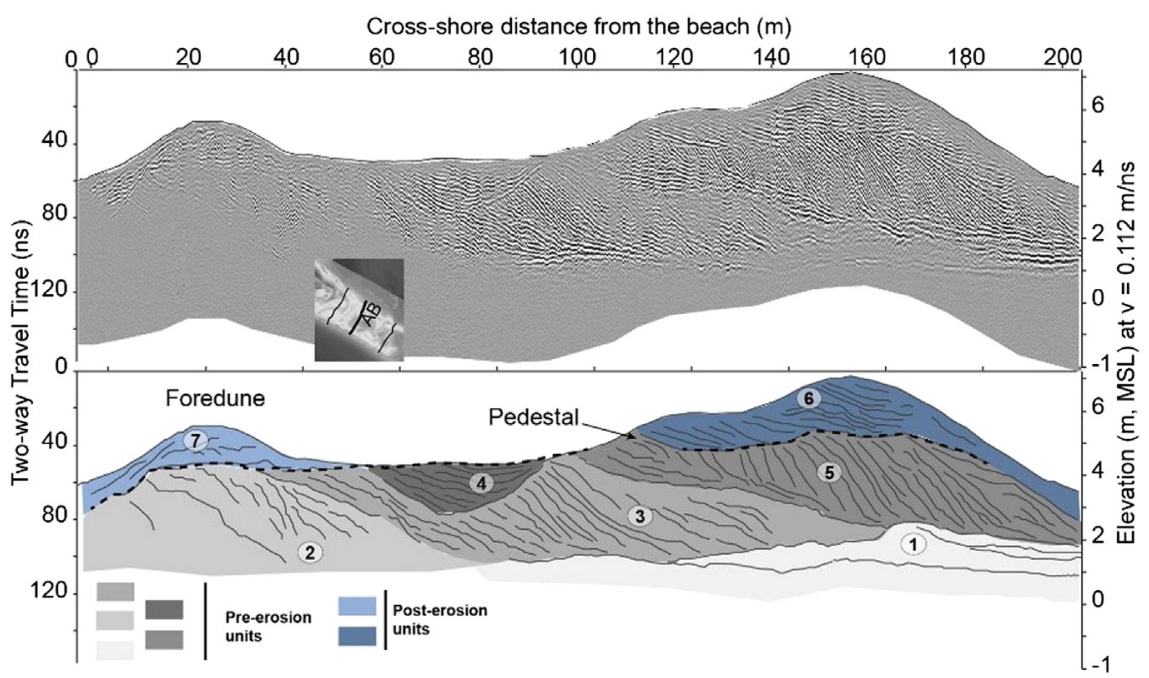

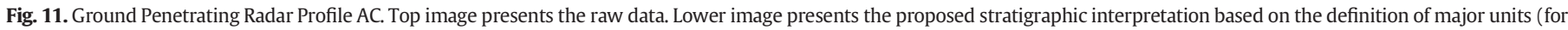

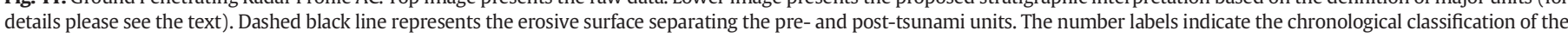
identified units labels. 


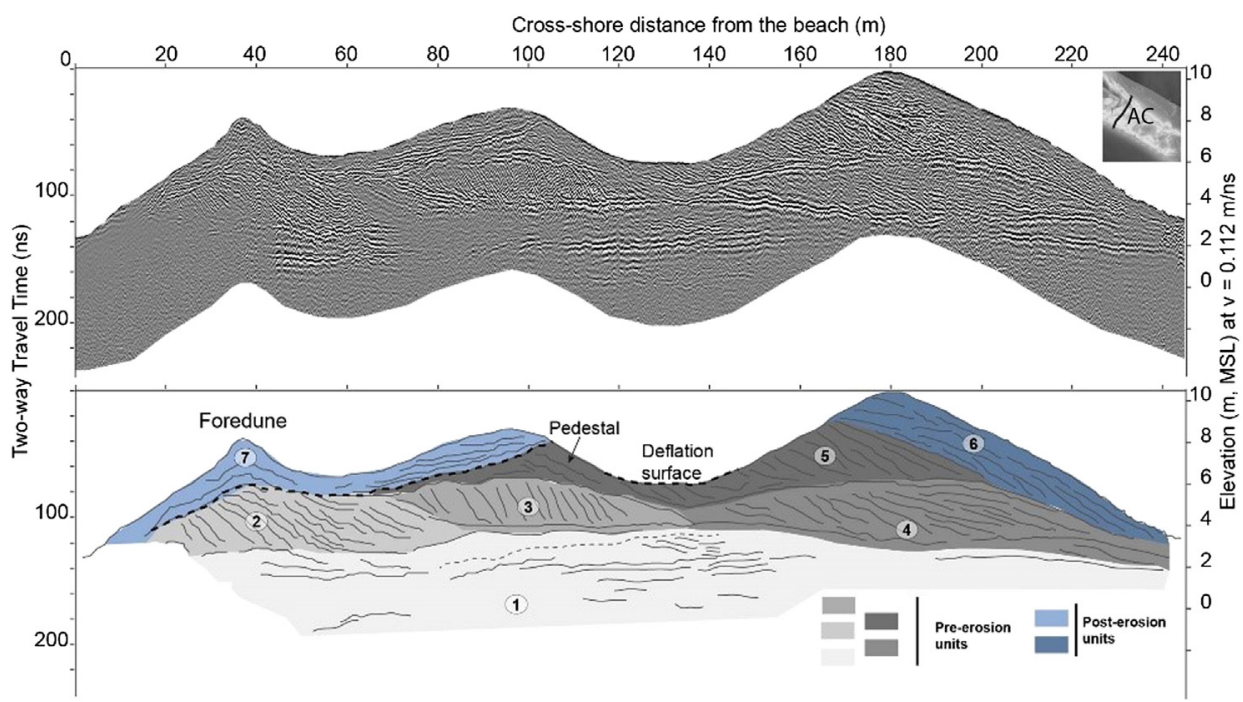

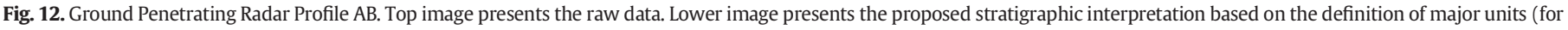

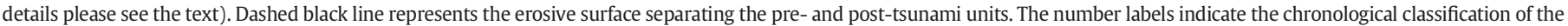
identified units labels.

recent vertical accumulation of aeolian sediments within a vegetated hummocky foredune (Unit 7, Fig. 9).

\subsubsection{Profile $A H$, stratigraphy and interpretation}

Profile AH runs across the barrier in Alcantarilha. In this case the internal configuration shows higher variability with the typical radar packages representing transgressive units rolling inland (Units 3 to 5 ,
Fig. 10) and overlaying ones characterized by hummocky internal configurations representing foredune deposits (Unit 2). Foredune deposits overlay radar packages interpreted as backshore and foreshore sections of a beach (Unit 1), documenting seaward progradation of the barrier. Similarly to profile AF, radar packages in the profile appear truncated by a sub-horizontal surface that runs between 30 and $130 \mathrm{~m}$ inland (Fig. 10). The surface is overlain by undulating sets of cross-laminae
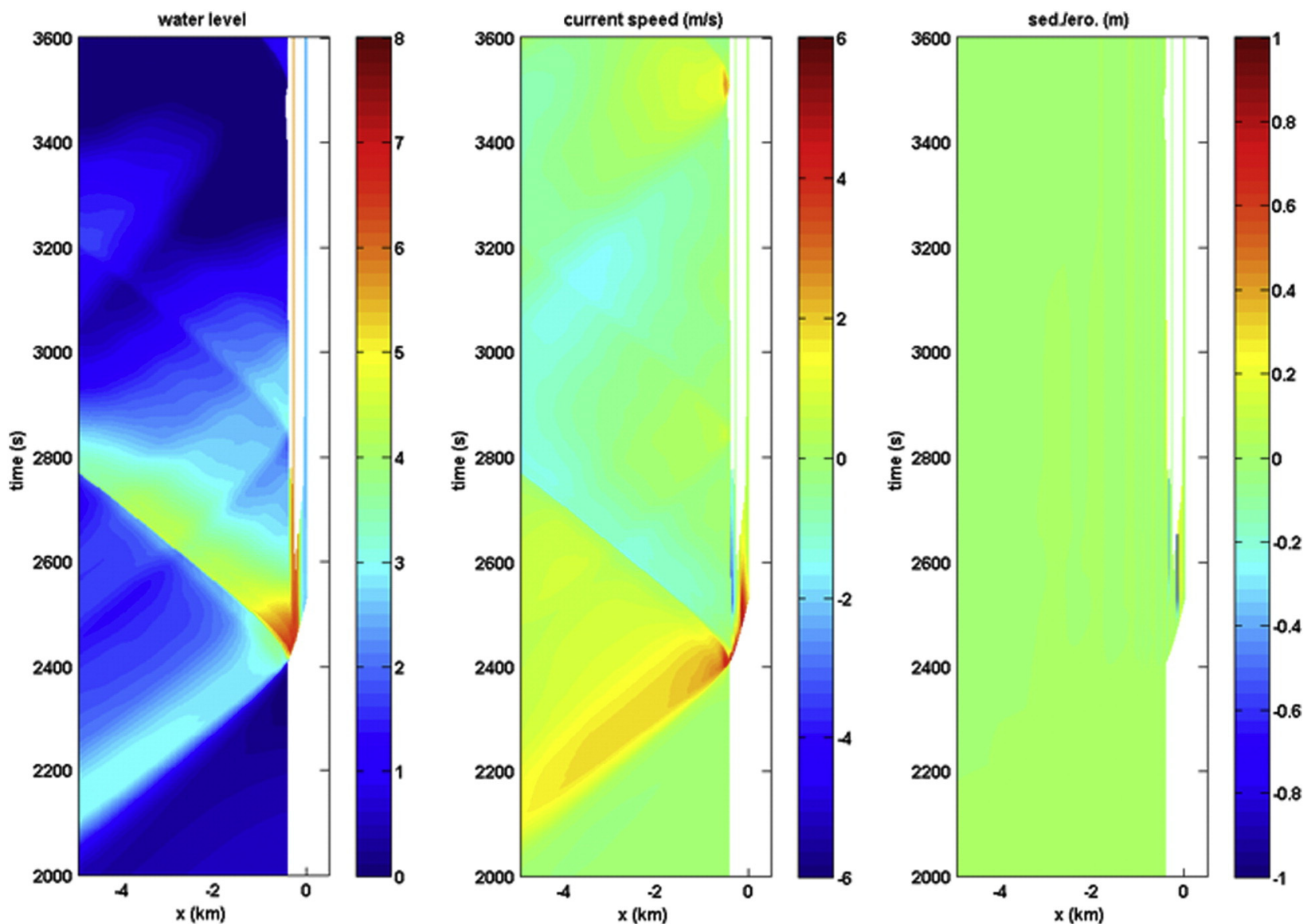

Fig. 13. Time-stack plots (parameter as function of cross-shore distance and time) of water level, velocity and cumulative sedimentation/erosion, for a profile with 6 m crest height. 
and oblique reflections dipping seaward (Unit 7). The latter documents the sedimentation of new foredunes and the progradation of the barrier seaward. The continuity of this surface is interrupted by a prominent feature (with its minimum height at 6-7 m above msl) located $80 \mathrm{~m}$ from the present shoreline (Fig. 10). This feature is interpreted as a remnant of the partially eroded transgressive dunes. Combining this information with the high resolution DTM, we interpret this prominent feature as the erosional horns of the blowouts developed on the barrier surface. Finally, Unit 6 is formed by a thin layer of sediments represented by massive patterns in the radargram likely related to the remobilization of sand at the surface, or bioturbation.

\subsubsection{Profile $A B$, stratigraphy and interpretation}

Further east, near Salgados inlet, profile $A B$ is characterized by the presence of two dune ridges. The first is located in the proximity of the present shoreline and represents the foredune ridge whereas the second has developed on the inland sector of the profile (Fig. 11). A depression located around $4.5 \mathrm{~m}$ above msl separates both ridges. Similar to the profiles obtained in Alcantarilha, this one is dominated by vertically stacked radar packages of landward dipping reflections (Units 2 to 5), suggesting the landward migration of dunes and vertical growth of the barrier. Transgressive units overlay a sub-horizontal surface characterized by high amplitudes interpreted as lagoonal deposits on top of which the barrier is migrating inland (Unit 1). Most of the radar packages of transgressive dunes are truncated by an erosive surface gently dipping seaward and located approx. $5 \mathrm{~m}$ above msl (Fig. 11). This surface resembles the erosive surface identified within the Alcantarilha profiles, located at similar elevations. In this case, the erosive surface is overlaid by Unit 7 at the seaward sector of the profile and Unit 6 at its inland part. The first represents foredune deposits, suggesting the local vertical growth of the barrier through aeolian sedimentation. The second is represented by a new transgressive unit likely related to the inland migration of parabolic dunes over the erosive surface. Also in this profile, it was possible to identify a prominent feature in Unit 5, which may indicate the occurrence of an erosive wall or pedestal. As in the previous profiles, such prominent features may have two possible origins. If they represent erosive walls, they are generated by aeolian flow erosion and the advance of blowouts. Conversely, if those features represent pedestals, they could have been generated through the erosion of aeolian dunes during barrier inundation by water flows (Goff et al., 2009). Unlike the profiles taken at Alcantarilha, radar packages representing foreshore deposits were not identified here.

\subsubsection{Profile $A C$, stratigraphy and interpretation}

Profile AC, located west of Profile AB, further away from Salgados inlet, consists of three dune ridges separated by two interdune depressions located around $6 \mathrm{~m}$ above msl (Fig. 12). This profile is dominated by vertically-stacked radar packages of landward-dipping reflections (Units 2 to 5). Likewise, the latter overlay a sub-horizontal surface interpreted here as representing the contact with lagoonal deposits (Unit 1, Fig. 12). In this case, the transgressive aeolian units located at the seaward half of the profile (i.e. Units 2, 3 and 5) appears truncated by an erosive surface dipping seaward that could be compared to the erosive surfaces identified within the other profiles reaching around $8 \mathrm{~m}$ above msl. In this case, this surface is overlain on the seaward side by a package with concave reflections representing foredune sedimentation (Unit 7). The dune ridge separating both depressions is composed of remnants of the transgressive aeolian Unit 5 (Fig. 12). This feature is backed by a second interdune depression, which likely originated from (Aeolian) deflation associated with a blowout or the inland migration of parabolic dunes, as inferred from comparison with the DTM. In turn, the formation of this blowout could explain the packages of transgressive dunes (Unit 6), covering the erosional walls and contributing to the vertical and lateral growth of the dune ridge (Fig. 12).

\section{4. $1 D$ simulation of the tsunami wave impact over the barrier}

The results of the XBeach simulations can be visualized in the socalled timestack plots, where the parameters water level, velocity and cumulative erosion/sedimentation are colour-coded as a function of cross-shore distance and time (Fig. 13). Only the simulation with just the crest height lowered to $6 \mathrm{~m}$ above msl is presented here. In Fig. 13, left panel, the tsunami wave propagates towards the shore until $2420 \mathrm{~s}$, increasing in height, especially at the dune seaward slope where the maximum water level reaches $6.7 \mathrm{~m}$. It is possible to see that a large part of the tsunami wave is reflected back as a wave with a very steep front and crest higher than that of the following incident wave. The shoreward velocities (middle panel) increase to over $4 \mathrm{~m} / \mathrm{s}$ during the overtopping, and as the flow rushes down the back of the dune. Results in the right panel show that the erosion and sedimentation take place during the passage of the first overtopping tsunami wave (visible in narrow blue and red bands) and little happens after this. The differences between the simulations for the three different profiles are shown in Fig. 4, where the minimum and maximum water levels during the simulation are shown, as well as the initial and final profiles. In the first profile the tsunami does not overtop the highest dune crest, though it does reach it by overtopping the foredune. There is some deposition in the dune trough, smaller undulations on the first dune front are smeared out and there is overall net erosion of the area between $4 \mathrm{~m}$ and $6 \mathrm{~m}$ above msl, the reworked sediment being deposited as a thin layer on the seaward slope of the dune and beach.

For the profile with lower crest height of $6 \mathrm{~m}$ above $\mathrm{msl}$, there is significant overtopping and the landward end of the dune is eroded by up to $1.5-2 \mathrm{~m}$ over a distance of some $10 \mathrm{~s}$ of meters, resulting in a steep landward slope and a deposition area over a length of $\sim 80 \mathrm{~m}$, with the thickness of the deposit in the order of several decimeters. As Test-03 shows, the maximum water level increases to approx. $7 \mathrm{~m}$ above $\mathrm{msl}$, as the tsunami is less reflected but rather runs up the slope and over the dune (Fig. 4). The erosion of the back of the dune is deeper and over a larger width and the deposition behind the dune increases likewise. The timing of the tsunami with a relatively high tide level is important in this case: without the extra $1 \mathrm{~m}$ water level at the boundary, the first wave of the tsunami is just able to reach the back and landward end of the dune in simulations with lower dune profiles (Test-02 and Test-03) but is hardly able to cause any erosion there.

\section{Discussion}

This work addresses the study of depositional (fan and sand sheet) and erosional features (through GPR and dune morphological analysis (scarps, pedestals, etc.) related to the AD 1755 tsunami in a coastal sector in south Portugal (Fig. 1). These tsunamigenic signatures were studied in the Alcantarilha lowland and compared with the adjacent Salgados lowland where the deposit from that tsunami was previously described by Costa et al. (2012). At both sites, a sand sheet was observed in the top of the lowlands' stratigraphy. This deposit contrasts with those resulting from present-day and late Holocene sedimentation regime characterizing both lowlands, dominated by low-energy (muddy) sedimentation. This sand sheet had a maximum thickness of $50 \mathrm{~cm}$ (more typically around $10 \mathrm{~cm}$ ) and extended inland for approx. $1 \mathrm{~km}$. The sedimentological, textural, compositional and micropalaeontological features previously reported (e.g. basal abrupt contact, fine and thinning inland, presence of rip-up clasts, bioclast content, heavy mineral and foraminifera assemblages) and the previously established chronological framework for the lowland deposits allow for a clear association with the AD 1755 tsunami (Costa et al., 2012; Hoska et al., 2014).

At the western tip of the barrier (Alcantarilha sector), where the dune is lower, the emplacement of a washover fan is attributed to dune overtopping by the AD 1755 tsunami wave, as previously suggested by Dinis et al. (2010). The sand fan in Alcantarilha also shares 
morphological features with tsunami deposits in similar coastal settings - muddy marsh successions in narrow coastal lowlands (Komatsubara et al., 2008), and partially fits the concept of a tsunami-scour fan (Goff et al., 2009) - and is supported by the GPR and aerial imagery data. Indeed, GPR data and older aerial photographs reveal the absence of a widespread erosional signature in the sand barrier - a result that is further supported by the numerical simulations obtained.

The exploratory model simulations on the morphological effects of the tsunami on the dune profile at Alcantarilha suggest that significant overtopping is likely to have occurred for dunes not much higher than $6 \mathrm{~m}$ above msl. During such an event, smaller-scale morphological features on the top of the dune would be erased, the back of the dune would be severely eroded and an overwash fan could be expected to be laid down up to about $100 \mathrm{~m}$ inland. The limitations in this analysis are: a) that the generation mechanism of the AD 1755 tsunami is inherently uncertain and only simulations for the most likely size of the event were carried out, calibrated with historical observations along the Portuguese coastline; $\mathrm{b}$ ) that the local model is $1 \mathrm{D}$ and ignores longshore variability and the possibility that the tsunami entered through the inlets and deposited sand parallel to the coast; c) that any variation in sediment size and possible vegetation effects are ignored; and d) we have no detailed information on the nature of the beach and beach-dune profile prior to the arrival of the tsunami in $1755 \mathrm{AD}$ (we assumed a coastal profile similar to present-day profile). Even considering these constraints, modelling results also suggest that overtopping of the Alcantarilha-Salgados barrier occurred through narrow and low areas such as those adjacent to the inlets (Figs. 6, 7, 13).

The historical record describes an extensive inundation in Alcantarilha lowland by the AD 1755, which implies that it was most likely completely flooded. The morphology of the lowland and barrier indicates that the Alcantarilha inlet might have concentrated a significant part of the inrushing tsunami flow, providing a preferred route for the massive inundation of the lowland. Moreover, even if the inlet was closed at the time of inundation, the overtopping occurred through the lower areas of the barrier, creating a depression in the dune field. Additionally, for a sufficiently high run-up at the coast, part of the incoming wave may have also overtopped low points of the dune crest. When the GPR data is analysed a minimum (and more accurate) runup can be established. The GPR results in Alcantarilha (in particular, Profiles $\mathrm{AF}$ and $\mathrm{AH}$ ) are in broad agreement with the values suggested elsewhere (Dinis et al., 2010) because the erosive surface observed at approx. $7 \mathrm{~m}$ is most likely the remnant erosional contact marking the impact of the AD 1755 tsunami waves when they overtopped this region of the dune field. This estimation supports hydro- and morphodynamic modelling results that suggest minor erosion in the foredune and overtopping heights compatible with GPR results. However, the dune field reaches up to $17 \mathrm{~m}$ above $\mathrm{msl}$ and the limited extent of the fan in Alcantarilha suggests that the dunes were not overtopped in the central and higher sector of the dune field. Assuming that the morphologies contemporaneous with the overwash are similar to presentday forms, the data presented here indicate that the run-up magnitude at the coast can be estimated as around $7 \mathrm{~m}$ above msl (corresponding to the maximum height of the erosive surfaces detected in the GPR profiles). This is slightly less than the described from other sedimentological studies on the AD 1755 tsunami deposit conducted in south Portugal that suggest a tsunami run-up at the coast $<10 \mathrm{~m}$ (e.g. Salgados - Costa et al., 2012; Boca do Rio - Oliveira et al., 2009). These data confirm that the run-up is $<10 \mathrm{~m}$, as previously stated, and allows further constraint to a range to $6-8 \mathrm{~m}$, confirming the role played by local morphological (e.g. topography, bathymetry, orientation of the coastline and lithology) characteristics in modulating this value.

In addition, the unit overlying older transgressive dunes interpreted as representing post-event deposits in Alcantarilha (Profile AF - Fig. 9) - were OSL dated in trench Alc30T (Fig. 1C and Table 2), yielding ages compatible with this interpretation for the upper $60 \mathrm{~cm}$ (approx. 250 years old), whereas the lower sediments of the trench
(60 to $180 \mathrm{~cm}$ below surface) documented older ages (around 300 years old). The multi-grain OSL ages for Alc $30 \mathrm{~T}$ (below $60 \mathrm{~cm}$ ) overestimate the known age of the tsunami deposit by several tens of years due to partial bleaching or the result of sediment mixing during the same depositional event as a consequence of the coastward and seaward water and sediment movements during a tsunami. This could be the case when tsunami waves incorporate older sediments from the dune surface and deposit them rapidly without substantial bleaching. Hypothetically, the short-lived event did not allow sufficient time for total bleaching. This is in line with previous results by Cunha et al. (2010) at Boca do Rio who showed similar overestimations and also suggested similar reasons for this. The upper three samples $(20-60 \mathrm{~cm}$ depth) are consistent with deposition of well-bleached aeolian sand on top of the tsunamigenic layer. Despite the age overestimation in the tsunami deposit it is clear that the Alc30T site has recorded the AD 1755 tsunami event (and post-impact sedimentation history). On the other hand, in Salgados, no evidence of overtopping was identified within Profile AC (height $>8 \mathrm{~m}$ above $\mathrm{msl}$ ), which in turn suggests that tsunami run-up was below $8 \mathrm{~m}$ above msl, in this location. This is further supported by Profile $A B$ in Salgados where it is possible to detect an erosional surface at approx. $6 \mathrm{~m}$ above msl analogous to the one observed in Alcantarilha. Thus, based on these results, the impacts of the AD 1755 event may have been considerably smaller (in intensity) than those derived from other modelling attempts, such as Omira et al. (2009).

Most of the results presented here suggest a relatively low impact of the tsunami over the coastal barrier mainly because of the likely high elevation of the dunes. However, it is important to highlight the fact that as a consequence of the inundation of the barrier, even if not complete, the impact seems to have been enough to destabilize the coastal dune and initiate the formation of scarps and pedestals and inland migration of parabolic dunes (Fig. 6). Similar features have been previously described in the literature in areas affected by tsunamis (Goff et al., 2009; Atwater et al., 2013) with remobilized sand being exposed to aeolian transport. Likewise, the integrated analysis of aerial imagery, GPR, maps and DTMs also revealed a number of pedestals within the dune sequence. The pedestals have not been reshaped since at least 1947 (earliest aerial photographic record). Considering that during the last century extreme storms that affected this coast (with wave heights above $5 \mathrm{~m}$ ) were not capable of changing or eroding these pedestals, their origin is mostly likely attributed to a unique extreme event - the AD 1755 tsunami. One can hypothesize that, although the AD 1755 tsunami impacts appear to have been smaller than initially thought, the present-day geomorphology is inherited from syn-event erosion of the lower areas of the barrier located within the seaward side, followed by later wind reshaping of a poorly or non-vegetated surface, temporarily increasing sediment availability for aeolian transport to generate parabolic dunes and blowouts.

It is to be expected that the results presented here should agree with recent work conducted in the aftermath of the 2004 Indian Ocean tsunami and the 2010 Chilean tsunami that focused on post-tsunami beach recovery. In fact, in Banda Aceh (Indonesia), approximately 1 year after the tsunami impact, the coastal system had apparently recovered its typical morphology and sedimentary profile (Li et al., 2012). Catalán et al. (2014) presented a case study of severe coastal erosion under the action of a moderate tsunami following the 2010 Maule Earthquake in Central Chile. An assessment of the recovery process of a sand barrier showed a recovery to nearly initial conditions within two years, with the most accelerated recovery phase during the first few months. Comparison between the case presented in this work and the ones above suggests that the Portuguese sites exhibit a long recovery time to extreme marine events of this magnitude and this is caused by differences in sediment input, climatic conditions and hydrodynamic regime (Goff et al., 2008). In agreement with Goff and Suguwara (2014) these conclusions stress the importance of tsunami events in the long-term evolution of coastal areas. 


\section{Conclusions}

This work devoted particular attention to erosional features of the AD 1755 tsunami, which are still visible in today's coastal landscape. This is of interest since the erosional features are often neglected in the study of palaeotsunami deposits in contrast to depositional imprints. Here, we show that the erosive signals detected through morphological and stratigraphic features (in conjugation with the depositional imprints observed) cannot be the result of storms and are most likely associated with the AD 1755 tsunami.

The multidisciplinary approach (involving lithostratigraphy, historical documents, textural parameters, geomorphological mapping, GPR, OSL dating and hydrodynamic and morphodynamic modelling) followed in this work facilitates the definition and understanding of the morphodynamic processes related with the AD 1755 tsunami inundation. For example, the radargram obtained for the tsunamigenic sand deposited over the barrier lacks clear internal structures and, in cases, its top displays massive patterns related to either post-event remobilization of sand or bioturbation. Only the correlation of lithostratigraphy, GPR and geomorphological mapping allowed for a holistic interpretation of the depositional and erosional evidences of the AD 1755 tsunami in this region. These results can be used to further constrain tsunami intensities and wave heights - factors that are important for coastal communities in terms of exposure to tsunami hazard.

Here, we critically assessed the historical information and using additional data we have quantified tsunami intensity in that region. It is likely that a tsunami of the magnitude of the AD 1755 has a return period in the order of 2-3 millennia (as observed in the geological record, the $\mathrm{AD} 1755$ deposit is unique in the coastal stratigraphy). Furthermore, based on GPR data, the spatial distribution of the deposit and hydrodynamic modelling, it was possible to constrain the AD 1755 tsunami runup in the study area to between 6 and $8 \mathrm{~m}$ above msl. Moreover, we show that the maximum elevation of the free surface of the ocean at the coast generated by this tsunami may be assessed by correlating the spatial distribution of its depositional signature (landward of the coastline) with the erosive imprint preserved in the overtopped barrier.

\section{Acknowledgements}

To Dr. Delminda Moura for providing us with GPR data collected in the frame of previous projects that helped us to plan the GPR survey presented here. The authors are particularly thankful to Dr.J. Dinis (University of Coimbra) for his initial involvement in this work, and we wish him a fast recovery. P. Costa benefited from an FCT Post-Doc scholarship (SFRH/BPD/84165/2012), R. González-Villanueva was funded by an IDL (Pest-OE/CTE/LA0019/2013) and a Xunta de Galicia (PlanI2C-ED481B 2014/132-0)-Post-Doc fellowships and M. A. Oliveira from an FCT PhD scholarship (SFRH/BD/66017/2009). S. Costas was funded by a research grant within the EU FP7 research project RISC-KIT-GA-2013-603458 and "FCT Investigator" program (ref. IF/01047/2014). The authors wish to acknowledge several Department colleagues and students that helped during the field campaigns in Alcantarilha and to LNEG for allowing the use of the GPR. The authors wish to thank two anonymous reviewers for the very constructive comments and suggestions that greatly improved the manuscript. Pedro P. Cunha was funded by the Fundação para a Ciência e a Tecnologia, through project UID/MAR/ 04292/2013 - MARE.

\section{References}

Andrade, C., 1990. O Ambiente de barreira da Ria Formosa (Algarve, Portugal). PhD, Lisboa, 645 pp.

Andrade, C., 1992. Tsunami generated forms in the Algarve Barrier Islands (South Portugal). Science of Tsunami Hazards 10 (1), 21-34.

Atwater, B.F., Cisternas, M., Yulianto, E., Prendergast, A.L., Jankaew, K., Eipert, A.A., Starin Fernando, W.I., Tejakusuma, I., Schiappacasse, I., Sawai, Y., 2013. The 1960 tsunami on beach-ridge plains near Maullín, Chile: landward descent, renewed breaches, aggraded fans, multiple predecessors. Andean Geol. 40 (3), 393-418.

Baptista, M.A., Miranda, J.M., Omira, R., Antunes, C., 2011a. Potential inundation of Lisbon downtown by a 1755-like tsunami. Nat. Hazards Earth Syst. Sci. 11, 3319-3326.

Baptista, M.A., Miranda, J.M., Omira, R., Antunes, C., 2011b. Potential inundation of Lisbon downtown by a 1755-like tsunami. Nat. Hazards Earth Syst. Sci. 11 (12), 3319-3326.

Bristow, C.S., Chroston, P.N., Bailey, S.D., 2000. The structure and development of foredunes on a locally prograding coast: insights from ground-penetrating radar surveys, Norfolk, UK. Sedimentology 47 (5), 923-944.

Buynevich, I.V., FitzGerald, D.M., Goble, R.J., 2007. A 1500 yr record of North Atlantic storm activity based on optically dated relict beach scarps. Geology 35 (6), 543-546.

Catalán, P.A., Cienfuegos, R., Villagrán, M., 2014. Perspectives on the long-term equilibrium of a wave dominated coastal zone affected by tsunamis: the case of central Chile. Journal of Coastal Research (Special Issue 71 - Coastal Erosion and Management along Developing Coasts) 55-61.

Costa, P.J.M., Andrade, C., Freitas, M.C., Oliveira, M.A., Jouanneau, J.M., 2009. Preliminary results of exoscopic analysis of quartz grains deposited by a palaeotsunami in Salgados Lowland (Algarve, Portugal). J Coastal Res 39-43.

Costa, P., Andrade, C., Freitas, M., Oliveira, M., Lopes, V., Dawson, A., Moreno, J., Fatela, F., Jouanneau, J.-M., 2012. A tsunami record in the sedimentary archive of the central Algarve coast, Portugal: characterizing sediment, reconstructing sources and inundation paths. The Holocene 22 (8), 899-914.

Costas, S., FitzGerald, D., 2011. Sedimentary architecture of a spit-end (Salisbury Beach, Massachusetts): the imprints of sea-level rise and inlet dynamics. Mar. Geol. 284 (1-4), 203-216.

Cunha, P.P., Buylaert, J.P., Murray, A.S., Andrade, C., Freitas, M.C., Fatela, F., Munhá, J.M., Martins, A.A., Sugisaki, S., 2010. Optical dating of clastic deposits generated by an extreme marine coastal flood: the 1755 tsunami deposits in the Algarve (Portugal). Quat. Geochronol. 5 (2-3), 329-335.

Daniels, D.J., 1996. Surface-penetrating Radar. Institute of Electrical \& Electronics Engineer.

Davis, J.L., Annan, A.P., 1989. Ground-penetrating radar for high resolution mapping of soil and rock stratigraphy. Geophys. Prospect. 37 (5), 531-551.

Dawson, A.G., 1994. Geomorphological effects of tsunami run-up and backwash. Geomorphology 10 (1-4), 83-94.

Dinis, J., Andrade, C., Oliveira, M.A., Freitas, M.C., Cunha, P.P., Martins, A., Costa, P., 2010 Geomorphological Constraining of Tsunami (?) Run-up in the Alcantarilha Coastal Lowland (Central Algarve, Portugal), Conferência Coastal Hope - Iberian Coastal Holocene Paleoenvironmental Evolution, Lisbon, Portugal.

Dougherty, A.J., FitzGerald, D.M., Buynevich, I.V., 2004. Evidence for storm-dominated early progradation of Castle Neck barrier, Massachusetts, USA. Mar. Geol. 210 (14), 123-134.

Duller, G.A.T., 2003. Distinguishing quartz and feldspar in single grain luminescence measurements. Radiat. Meas. 37, 161-165.

Esaguy, A., 1984. Ria de Faro - Barra da Armona - Evolução 1873-1983. Direcção Geral de Portos, Lisbon.

Fagherazzi, S., Du, X., 2008. Tsunamigenic incisions produced by the December 2004 earthquake along the coasts of Thailand, Indonesia and Sri Lanka. Geomorphology 99 (1-4), 120-129.

Goff, J.R., McFadgen, B.G., 2002. Seismic driving of nationwide changes in geomorphology and prehistoric settlement-a 15th Century New Zealand example. Quaternary Science Reviews 21 (20-22), 2229-2236.

Goff, J.R., Lane, E., Arnold, J., 2009. The tsunami geomorphology of coastal dunes. Nat Hazards Earth Syst. Sci. 9 (3), 847-854.

Goff, J., McFadgen, B., Wells, A., Hicks, M., 2008. Seismic signals in coastal dune systems. Earth Sci. Rev, 89 (1-2), 73-77.

Goff, J., Sugawara, D., 2014. Seismic-driving of sand beach ridge formation in northern Honshu, Japan? Marine Geology 358, 138-149.

González-Villanueva, R., Costas, S., Pérez-Arlucea, M., Jerez, S., Trigo, R.M., 2013. Impact of atmospheric circulation patterns on coastal dune dynamics, NW Spain. Geomorphology 185 (0), 96-109.

Grant, J.A., Brooks, M.J., Taylor, B.E., 1998. New constraints on the evolution of Carolina bays from ground-penetrating radar. Geomorphology 22 (3-4), 325-345.

Gusman, A.R., Tanioka, Y., Takahashi, T., 2012. Numerical experiment and a case study of sediment transport simulation of the 2004 Indian Ocean tsunami in Lhok Nga, Banda Aceh, Indonesia. Earth Planet Sp 64 (10), 817-827.

Hayakawa, Y.S., Oguchi, T., Saito, H., Kobayashi, A., Baker, V.R., Pelletier, J.D., McGuire, L.A. Komatsu, G., Goto, K., 2015. Geomorphic imprints of repeated tsunami waves in a coastal valley in northeastern Japan. Geomorphology 242, 3-10.

Hoska, N., Fatela, F., Costa, P., Andrade, C., Oliveira, M.A., Freitas, M.C., 2014. Contribution of Foraminifera to Discriminate Depositional Events within an apparently Massive Tsunami Deposit, AGU Fall Meeting, San Francisco, USA.

Kain, C., Gomez, C., Wassmer, P., Lavigne, F., Hart, D., 2014. Truncated dunes as evidence of the 2004 tsunami in North Sumatra and environmental recovery post-tsunami. N. Z. Geogr. 70 (3), 165-178.

Komatsubara, J., Fujiwara, O., Takada, K., Sawai, Y., Aung, T.T., Kamataki, T., 2008. Historical tsunamis and storms recorded in a coastal lowland, Shizuoka Prefecture, along the Pacific Coast of Japan. Sedimentology 55 (6), 1703-1716.

Koster, B., Hoffmann, G., Grützner, C., Reicherter, K., 2014. Ground penetrating radar facies of inferred tsunami deposits on the shores of the Arabian Sea (Northern Indian Ocean). Mar. Geol. 351, 13-24.

Koster, B., Reicherter, K., Vott, A., Grutzner, C., 2011. Identifying sedimentary structures and spatial distribution of tsunami deposits with GPR - examples from Spain and Greece, Advanced Ground Penetrating Radar (IWAGPR). 2011 6th International Workshop on, pp. 1-6. 
Li, L., Huang Z., 2013. Modeling the change of beach profile under tsunami waves: a comparison of selected sediment transport models. Journal of Earthquake and Tsunami 07 (01).

Li, L., Qiu, Q., Huang, Z., 2012. Numerical modeling of the morphological change in Lhok Nga, west Banda Aceh, during the 2004 Indian Ocean tsunami: understanding tsunami deposits using a forward modeling method. Nat. Hazards 64 (2), 1549-1574.

Lindhorst, S., Betzler, C., Hass, H.C., 2008. The sedimentary architecture of a Holocene barrier spit (Sylt, German Bight): swash-bar accretion and storm erosion. Sediment. Geol. 206 (1-4), 1-16.

Lopes, J.B.L.S., 1841. Corografia ou Memória Económica, Estatística e Topográfica do Reino do Algarve, Lisboa.

Madsen, A.T., Murray, A.S., 2009. Optically stimulated luminescence dating of young sediments: a review. Geomorphology 109, 3-16.

Meilianda, E., Dohmen-Janssen, C.M., Maathuis, B.H.P., Hulscher, S.J.M.H., Mulder, J.P.M., 2007. Beach morphology at Banda Aceh, Indonesia in response to the tsunami on 26 December 2004. Coastal Sediments, New Orleans, United States 14.

Moore, L.J., Jol, H.M., Kruse, S., Vanderburgh, S., Kaminsky, G.M., 2004. Annual layers revealed by GPR in the subsurface of a prograding coastal barrier, Southwest Washington, U.S.A. J. Sediment. Res. 74 (5), 690-696.

Moura, D., Veiga-Pires, C., Albardeiro, L., Boski, T., Rodrigues, A.L., Tareco, H., 2007. Holocene sea level fluctuations and coastal evolution in the central Algarve (southern Portugal). Mar. Geol. 237, 127-142.

Murray, A.S., Marten, R., Johnston, A., Martin, P., 1987. Analysis for naturally occurring radionuclides at environmental concentrations by gammaspectrometry. J. Radioanal. Nucl. Chem. 115, 263-288.

Oliveira, M.A., Andrade, C., Freitas, M.C., Costa, P.J., 2009. Modeling volume transfer between beach-foredune and the backshore by the 1755 Lisbon tsunami at Boca Do Rio lowland, Algarve (Portugal). J. Coast. Res. 1547-1551.

Olley, J.M., Murray, A.S., Roberts, R.G., 1996. The effects of disequilibria in the uranium and thorium decay chains on burial dose rates in fluvial sediments. Quaternary Science Reviews (Quaternary Geochronology) 15, 751-760.

Omira, R., Baptista, M.A., Matias, L., Miranda, J.M., Catita, C., Carrilho, F., Toto, E., 2009. Design of a sea-level tsunami detection network for the Gulf of Cadiz. Natural Hazards and Earth System Science 9, 1327-1338.

Pessanha, L., Pires, H.O., 1981. Elementos sobre o clima de agitação marítima na costa sul do Algarve, unpublished report. Instituto Nacional de Meteorologia e Geofísica, Lisbon.

Pinto, C., Teixeira, S.B., 2002. Morphodynamics of the sandy barrier of Salgados coastal lagoon, Armação de Pêra Bay (Algarve - Portugal). In: Portugal, E. (Ed.), Eurocoast Littoral 2002. The Changing Coast. Eurocoast/EUCC, Porto, pp. 403-409.

Prescott, J.R., Hutton, J.T., 1994. Cosmic ray contributions to dose rates for luminescence and ESR dating: large depths and long-term variations. Radiat. Meas. 23, 497-500.

Quintela, M., Costa, P.J.M., Fatela, F., Drago, T., Hoska, N., Andrade, C., Freitas, M.C., 2016. The AD 1755 tsunami deposits onshore and offshore of Algarve (south Portugal): Sediment transport interpretations based on the study of Foraminifera assemblages, Quaternary International, Available online 15 January 2016, ISSN 1040-6182, http:// dx.doi.org/10.1016/j.quaint.2015.12.029.
Rebêlo, L., Costas, S., Brito, P., Ferraz, M., Prudêncio, M.I., Burbidge, C., 2013. Imprints of the 1755 tsunami in the Tróia Peninsula shoreline, Portugal. In: Conley, D.C., Masselink, G., Russell, P.E., O'Hare, T.J. (Eds.), 12th International Coastal Symposium. Journal of Coastal Research, Plymouth, England, pp. 814-819.

Rodríguez Santalla, I., Sánchez García, M.J., Montoya Montes, I., Gómez Ortiz, D., Martín Crespo, T., Serra Raventos, J., 2009. Internal structure of the aeolian sand dunes of El Fangar spit, Ebro Delta (Tarragona, Spain). Geomorphology 104 (3-4), 238-252.

Roelvink, D. Reniers, A, van Dongeren, A van Thiel de Vries, J. McCall, R. Lescinski, J. 2009. Modelling storm impacts on beaches, dunes and barrier islands. Coast. Eng. $56(11-12), 1133-1152$.

Schenk, C.J., Gautier, D.L., Olhoeft, G.R., Lucius, J.E., 2009. Internal Structure of an Aeolian Dune using Ground-Penetrating Radar, Aeolian Sediments. Blackwell Publishing Ltd., pp. 61-69.

Schneider, H., Höfer, D., Trog, C., Busch, S., Schneider, M., Baade, J., Daut, G., Mäusbacher, R., 2010. Holocene estuary development in the Algarve region (southern Portugal) - a reconstruction of sedimentological and ecological evolution. Quat. Int. 221 (1-2), 141-158.

Smit, P.B., Zijlema, M., Stelling, G.S., 2013. Depth-induced wave breaking in a nonhydrostatic, near-shore wave model. Coastal Engineering 76.

Stelling, G.S., Zijlema, M., 2003. An accurate and efficient finite-difference algorithm for non-hydrostatic free-surface flow with application to wave propagation. International Journal for Numerical Methods In Fluids 43.

Switzer, A.D., Bristow, C.S., Jones, B.G., 2006. Investigation of large-scale washover of a small barrier system on the southeast Australian coast using ground penetrating radar. Sediment. Geol. 183 (1-2), 145-156.

Taborda, R., Dias, J.A., 1992. Análise da Sobreelevação do Mar de Origem Meteorológica durante os Temporais de Fevereiro/Março de 1978 e Dezembro de 1981. Geonovas, A Geologia e o Ambiente 1, 89-97.

Tamura, T., 2012. Beach ridges and prograded beach deposits as palaeoenvironment records. Earth Sci. Rev. 114 (3-4), 279-297.

Topp, G.C., Davis, J.L., Annan, A.P., 1980. Electromagnetic determination of soil water content: measurements in coaxial transmission lines. Water Resour. Res. 16, 574-582.

Van Dam, R.L., 2001. Causes of Ground Penetrating Radar Reflections in Sediment PhD. thesis PhD Vrije Universiteit, Amsterdam.

Van Dam, R.L., Schlager, W., 2000. Identifying causes of ground-penetrating radar reflections using time-domain reflectometry and sedimentological analyses. Sedimentology 47 (2), 435-449.

Young, Y.L., Xiao, H., Maddux, T., 2010. Hydro- and morpho-dynamic modeling of breaking solitary waves over a fine sand beach. Part I: experimental study. Mar. Geol. 269 (3-4), 107-118.

Zijlema, M., Stelling, G.S., 2005. Further experiences with computing non-hydrostatic free-surface flows involving water waves. International Journal for Numerical Methods in Fluids 48

Zijlema, M., Stelling, G.S., 2008. Efficient computation of surf zone waves using the nonlinear shallow water equations with non-hydrostatic pressure. Coast. Eng. 55 